Security of Property Rights and Transition in Land Use

Denys Nizalov (Kyiv School of Economics/ University of Kent)

Suzanne Thornsbury (USDA Economic Research Service)

Scott Loveridge (Michigan State University)

Mollie Woods (Michigan State University)

Olha Zadorozhna (Lazarski University) 


\title{
Security of Property Rights and Transition in Land Use *
}

Denys Nizalov ${ }^{1}$, Suzanne Thornsbury ${ }^{2}$, Scott Loveridge ${ }^{3}$, Mollie Woods $^{4}$, Olha Zadorozhna ${ }^{5}$

\begin{abstract}
Price and yield uncertainty are traditional considerations in agricultural markets and their impact on development. Agricultural producers in transition economies face an additional risk factor - changes in the institutional protection of property rights. This paper illustrates how institutional uncertainty may affect investment, land use, and crop mix patterns. In particular, in the Ukrainian example, the rights of tenants are viewed as uncertain in anticipation of establishment of an open market for sale of agricultural land. Establishment of the land market in Ukraine has been postponed several times over the last fifteen years and a significant number of lease contracts are not formalized. A large panel of farm-level data was used to show that a higher share of rented land is associated with a lower share of land used for investment intensive perennial crops controlling for prices and other factors. The difference in response to uncertainty is found to be significant among three crop types: perennials, grains and oil crops. The implication is that the lower level of protection of use rights and uncertainty regarding the future regulation of land sales market leads to under-investments in more capital intensive crops. As a result, tenants deviate from the optimal crop mix, reducing the productivity of tenant farms. Farms under 200 ha are affected the most negatively as they are less likely to be able to access the level of legal and political protection enjoyed by large farms. As a result, Ukraine faces significant losses in the value of agricultural production and GDP in the short and longer run.
\end{abstract}

Keywords: property rights, agricultural development, crop mix, transition economy, Ukraine JEL classification: Q15, Q12, O13, O17, O24

\section{DO NOT CITE WITHOUT PERMISSION OF AUTHORS}

August, 2015

\footnotetext{
* This research project was partially supported by NSF Award CNH 0909378. The authors greatly appreciate the support from the State Statistics Service of Ukraine for their methodological comments and access to data.

${ }^{1}$ Corresponding author, Kyiv School of Economics/ University of Kent, nizalov@ @se.org.ua

${ }^{2}$ USDA Economic Research Service, sthornsbury@ers.usda.gov

${ }^{3}$ Michigan State University, loverid2@msu.edu

${ }^{4}$ Michigan State University, willi751@msu.edu

${ }^{5}$ Lazarski University, o.zadorozhna@lazarski.edu.pl
} 


\section{Introduction}

Price and yield uncertainty are traditionally considered to be important impediments in development of the agricultural sector and rural areas. Developed countries for example, often implement programs intended to reduce farmer exposure to price and yield fluctuations. In addition to these traditional sources of uncertainty, agriculture in transition economies faces additional uncertainty factor - changes in the institutional protection of property rights. This paper illustrates how such institutional changes affect the land use, crop mix patterns and landrelated investments in Ukraine.

Ukraine is often characterized as a "breadbasket" of Europe due to its agricultural prowess (Bezlepkina, van Berkum, and Rau, 2013). The country has some of the richest arable land in the world and is among the largest agricultural producers. For example, Ukraine belongs to the top 10 global producers and exporters of wheat, corn, and sunflower oil (FAO 2010). Ukraine has twice as much cropland as France and three times more than Germany or Poland; however, production remains at a low level compared to potential in the sector.

The State Statistics Committee of Ukraine publishes annual reports on the level of agricultural production by sub-sector (subsistence household farms vs. commercial farms; livestock vs. crop production) (Figure 1). In 2012 Ukraine's agricultural production level was only 79 percent of the 1990s (State Statistics Committee, 2013). This decline is driven primarily by a substantial drop in production by commercial farms (former collective farms), which produced 82 percent of agricultural output in 1990. These farms were largely affected by institutional changes in input and output markets as well by change in ownership, organizational structure and management. In contrast, household crop production continued its growth despite the turmoil of transition. Output from households more than doubled during the last 20 years. For many households, both in rural and urban areas, subsistence farming was one of the major coping strategies during the transition crisis and about 50 percent of households combine subsistence and commercial farming in 2012 (State Statistics Committee, 2012). 
Figure 1. Index of agricultural output, Ukraine, 1995-2012

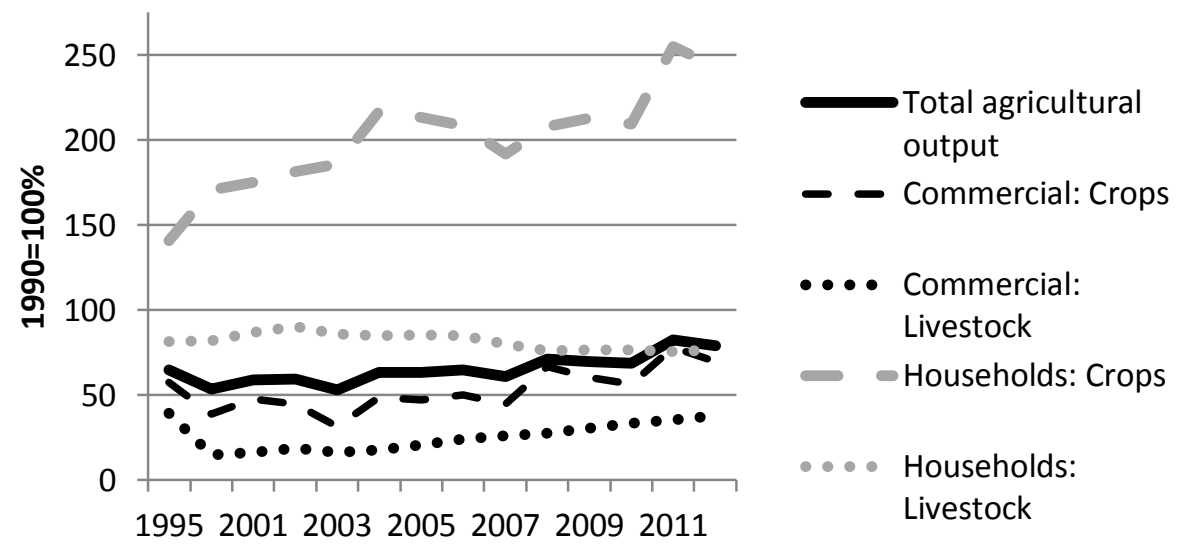

Data: State Statistics Service (2013).

Ukraine's declining agricultural output is mostly due to how the sector is organized, rather than depleted soils or droughts common in other parts of the world ${ }^{6}$. With world population predicted to rise to 9 billion by 2050, returning Ukrainian agriculture to its former productivity or expanding its output above former historic highs can be a key in addressing the global challenge of food security. Restoring Ukraine's agriculture could also reduce pressure to expand agriculture into fragile equatorial forest ecosystems needed to reoxygenate the air. Unlike many developing countries, increasing Ukraine's agricultural productivity is not overly dependent on varietal improvements or bringing new acreage into production. Ukrainian climate and soils are similar to highly productive systems in Western Europe, the U.S., and Canada, where there are high levels of agronomic research investment from both public and private sectors. Varietal improvements, if needed, should therefore not be difficult. As Ukraine's adult literacy rate is over 99 percent (UNESCO, 2009), adoption of new agricultural techniques should also present few difficulties in terms of human capital. Several cases of new industrial farms confirm this statement. Moreover, Ukraine is a very urbanized country ${ }^{7}$ with potential for efficient large-scale farming without the trauma of relocating a rural population.

This descriptive evidence may suggest that institutional changes that would reduce uncertainty and provide better protection of property rights, could contribute to agricultural

\footnotetext{
${ }^{6}$ Ukraine can be characterized as a land abundant country. The decrease in output is related primarily to decreased productivity of commercial farms (former collective) during 1990s. For further discussion see Deininger and Nizalov 2013; Nizalov and Thornsbury 2015.

${ }^{7}$ In 2012, 68.9 percent of population was urban (State Statistics 2013). With a rural population of 14M, roughly half $(6.8 \mathrm{M})$ are in the labor force; of them, $0.7 \mathrm{M}$ are employed in agriculture.
} 
output growth, improvement of the national trade balance and would contribute to global food security. These changes are likely to be addressed by the new government as a part of its Development Strategy 2020. Accession to WTO in the mid-2000s and signing the Trade Agreement with the EU opens up additional opportunities for agricultural export and provides incentives for expansion. However, an empirical evidence is needed to support the above conclusion and the proposed development strategy.

While all countries face changes in regulations, the case of Ukraine provides an important lesson. The design and schedule for new regulation introduction has to be communicated clearly and introduced within a reasonable time frame to reduce uncertainty in investment decision making by private sector.

Besides addressing the practical importance of property rights protection, this paper contributes to a large literature on agricultural productivity. Several papers explain the gap in agricultural productivity with misallocation of labor (starting with Rosenstein-Rodan (1943), Lewis (1955), and Rostow (1960) to more recent Gollin et al. (2014)) and capital (e.g. Restuccia and Rogerson (2008) and Hsieh and Klenow (2009)). This paper shows that misallocation of land is yet another reason for productivity gap. The role of institutions is critical in this misallocation. Hall and Jones (1999), and Acemoglu, Johnson, and Robinson (2001) among others shown the importance of strong land property rights in improving mobility and allocation

of labor in the agricultural sector. This paper provides empirical evidence that unsecure rights for land lead to allocation of land to less risky but lower value added and less capital intensive crop enterprises.

The rest of the paper is structured as follows. Section two overviews agricultural sector and land reforms in Ukraine. Next, a model for testing the impact of unsecure rights is presented. Part four presents the data. The model is followed by the estimation results, implications and conclusions.

\section{Structure of Ukrainian Agriculture}

Ukrainian farms can be broadly classified into two sectors: individual (or household) and corporate (Lerman et al., 2006). In 2004, there were approximately 8,900 large corporate farms, which were primarily the successors to former collective and state farms. The corporate farms cultivated 59 percent of national agricultural land, and supplied 30 percent of the gross 
agricultural output (GAO). Individual (household) farms included approximately 5.3 million household plots, accounting for 33 percent of the agricultural land and 60-65percent of the GAO. The output from these household plots was primarily used for own consumption or supplemental income. Comparison of land use and output shares across these two groups confirms the earlier conclusion about low productivity of commercial farms presented in Figure 1. There were also approximately 43,000 independent smallholders who relied on agricultural sales as a major source of household income. This group in aggregate accounted only for 8 percent of the agricultural land and 5-10 percent of GAO, which indicates that their productivity is higher than corporate farms, but lower than household subsistence farms. During the early 2000s, Ukrainian agriculture went through a major transformation as land and other factor markets were liberalized in pre-accession to WTO. However, there has been a ban on sales transactions for agricultural land (Moratorium) that was established in December of 2001. Instead of sales, a vibrant land rental market emerged. This period was also marked by an expansion of large commercial farms (Deininger and Nizalov, 2013), an increase in productivity, and change in crop mix.

The State Statistics Service (SSS) of Ukraine collects annual reports on inputs and outputs for the universe of corporate farms via reporting Form 50AG and on a sample of smallholder producers via Form 2 Farm. Additional data on individual subsistence (household) farms is collected via household surveys. This paper is focused on corporate farms and relies on data collected with Form 50AG. These farms cultivate about 89 percent of commercially farmed land and are most likely to be involved in global food markets and trade. ${ }^{8}$ The commercial agricultural sector was most impacted by the institutional transformation and, thus, is an ideal case for exploration of impact of institutional changes on investments, output and land use.

As of 2012, corporate farms operate primarily on rented land (Table 1). Only a small share of land, acquired before 2001 and inherited from former state farms, was owned directly by the corporate farms. The share of rented land increased by 1.4 percentage points between 2004 and 2012, reflecting the fact that older and less efficient commercial farms went out of business or rented out the land they own to more productive users (see Deininger and Nizalov 2013).

\footnotetext{
${ }^{8}$ For more details on Ukrainian farm structure see Nizalov et al. (2015)
} 
Table 1. Corporate farm crop mix and rental share

\begin{tabular}{|c|c|c|r|r|r|r|r|c|}
\hline Year & \begin{tabular}{c} 
Rented \\
land, \\
\cline { 3 - 9 } \\
\cline { 3 - 9 } \\
sherage
\end{tabular} & $\begin{array}{c}\text { Perennial } \\
\text { crops }\end{array}$ & $\begin{array}{c}\text { Oil } \\
\text { crops }\end{array}$ & $\begin{array}{l}\text { Grain } \\
\text { crops }\end{array}$ & $\begin{array}{l}\text { Perennial } \\
\text { crops }\end{array}$ & Oil crops & $\begin{array}{c}\text { Grain } \\
\text { crops }\end{array}$ & All crops \\
\hline 2004 & 92.96 & 0.66 & 8.05 & 46.77 & 74,622 & $1,837,708$ & $7,916,141$ & $17,238,671$ \\
\hline 2008 & 94.16 & 0.50 & 20.01 & 50.52 & 42,246 & $3,792,098$ & $8,819,438$ & $17,065,538$ \\
\hline 2012 & 94.38 & 0.48 & 25.31 & 47.46 & 31,463 & $4,506,387$ & $8,293,280$ & $17,122,710$ \\
\hline
\end{tabular}

Source: State Statistics Service (Form 50AG)

Note: * - other crops not reported in the table include root, technical and feed crops, and vegetables.

There was also a large transformation in the crop mix between 2004 and 2012. About 50 percent of land cultivated by corporate farms has consistently been used for production of grain crops. While the aggregate share of these grain crops did not change much, the share of corn increased significantly, driving up overall grain output and profitability per hectare (Table 2). There was also a shift in geographical distribution of grain crops (Figure $2 b$ and $2 \mathrm{e}$ ). The share of grain crops decreased slightly in southern regions, but increased in western and eastern parts.

In contrast, the average share of oil crops (Table 1), led by sunflower, more than tripled (from 8 percent in 2004 to 25 percent in 2012) and the total land area more than doubled. Strong international prices and increased oilseed productivity seem to be responsible for this shift. As the profitability of sunflowers more than doubled, it provided a strong incentive for such shift. ${ }^{9}$ The sunflower expansion took share away from other non-grain crops. The geographic range of oil crops expanded from southeast (Figure 2c) to other southern and western regions of the country (Figure 2f).

Table 2. Ukraine crop productivity (kg/ha) and profitability (USD/ha)

\begin{tabular}{|r|r|r|r|r|r|r|}
\hline & \multicolumn{3}{|c|}{ Productivity, Kg/ha } & \multicolumn{3}{c|}{ Profitability, USD/ha } \\
\hline Year & Perennial crops & Oil crops & Grain crops & Perennial crops & Oil crops & Grain crops \\
\hline 2004 & 1,926 & 1,001 & 2,512 & 316 & 310 & 324 \\
\hline 2008 & 2,624 & 1,675 & 3,158 & 768 & 493 & 424 \\
\hline 2012 & 5,736 & 1,788 & 2,778 & 1,773 & 774 & 515 \\
\hline
\end{tabular}

Source: State Statistics Service (Form 50AG)

\footnotetext{
${ }^{9}$ The estimates of profitability are calculated as difference in value of output for a particular crop and the total cost of production. Value of output is total crop output times the district (rayon) average price. The value of family labor is not taken into account. However, for the corporate farms considered here, the use of family labor is minimal.
} 
Figure 2. Distribution and change in the crop mix, Ukraine, 2004-2012
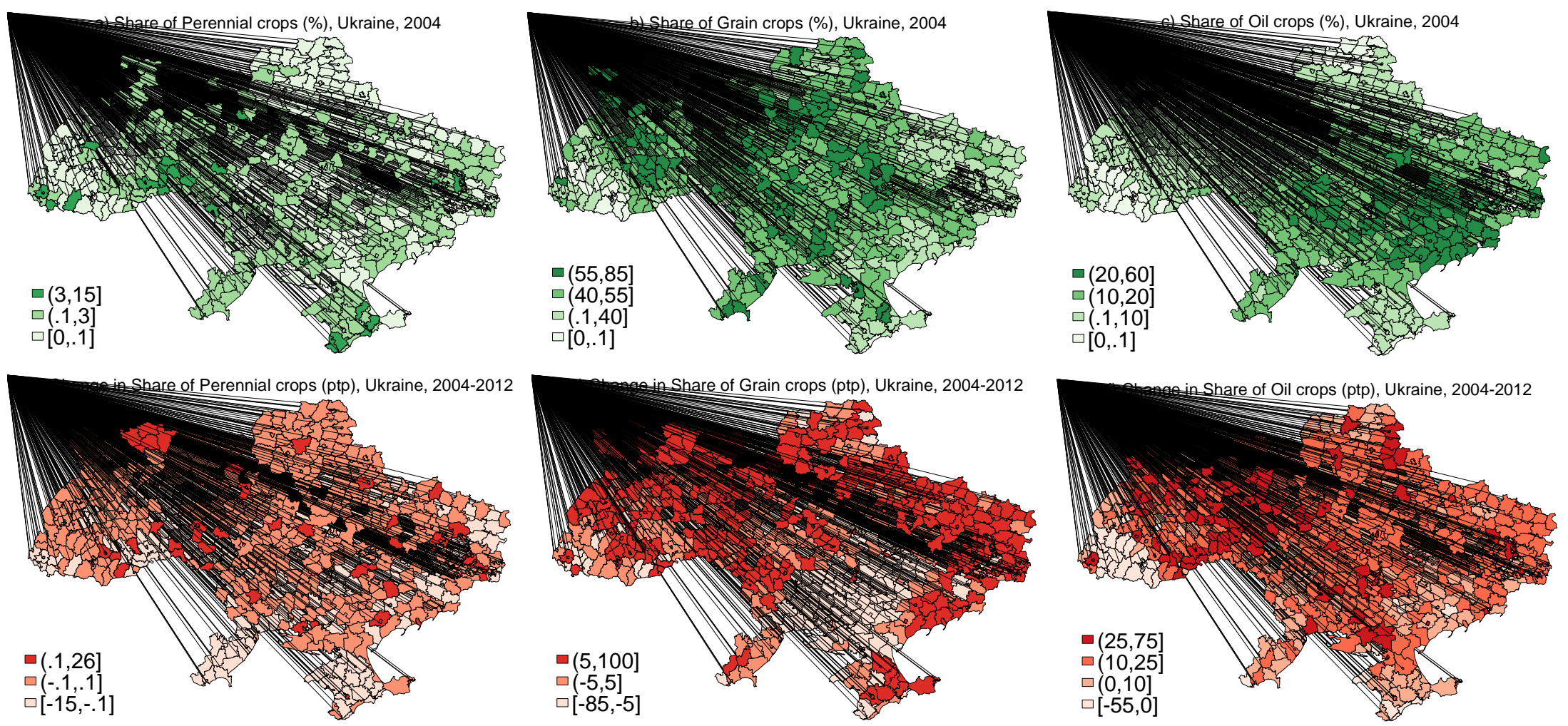

Note: Share of cultivated land used for perennial, grain and oil crops. Source: State Statistics Form 50 AG 
The perennial crops (tree fruit, berries, grapes) show a very different tendency. Both the share and total land area under perennial crops contracted and the number of producers has declined. The average share of cropland decreased from 0.66 percent to 0.48 percent and the total area declined from 74.6 thousand hectares to 31.5 thousand hectares. The decrease was primarily in the areas that specialized in perennial crop production (Figures $2 \mathrm{a}$ and $2 \mathrm{~d}$ ). Over the same period, productivity and profitability of perineal crops increased relative to oil crops and grains. While all three crop types returned about the same profitability per hectare in 2004 (as would be expected under stable and efficient market conditions), profitability of perennial crops had increased almost 6 times and productivity more than doubled by 2012 (Table 2). The average profitability of perennial crops was about 1,773 USD per ha while for the oil crops and grains it was 774 USD per ha and 515 USD per ha, respectively. It would be reasonable to expect that in the longer run the share of perennial crops would increase. Moreover, an increase in population income level and an increase in import of fruits could be a sign of increased demand and would support this expectation. However, the observed deviation from the optimal crop mix may point to some market imperfections in input or output markets for perennial crop production. Institutions may play a key role in explaining this puzzle, calling for the more careful analysis presented below.

\section{Land reforms in Ukraine}

Ukraine experienced major changes in institutional regulation and protection of property rights for land as a part of the transition from a centrally planned to a market economy. In 1990, at the beginning of the transition, all land belonged to the state (Article 11 of the Constitution of the Ukrainian SSR, 1978) and was operated by state enterprises. The land reform started in 1991 with the Parliament resolution "On the Land Reform" and the 1992 Law of Ukraine "On the Forms of Land Tenure”. By 1995, most of the state farms had been reorganized into collective farms. Ownership for about 40 percent of agricultural land had been transferred to these farms and their employees collectively. The Constitution of Ukraine (enacted in 1997) established that property rights for land could belong to citizens, legal entities, local communities, or the State. Still, individual property rights to agricultural land were almost nonexistent until 1999 when the Presidential Decree “On Urgent Measures to Accelerate Reform in Agriculture” granted individual members of collective enterprises with rights to withdraw their parcels from the 
collective. Consequently, collective ownership practically disappeared (Figure 3). However, in most cases, individuals who received agricultural land during 90s had no working capital, equipment, or capacity for independent farming. Many of these new owners had only two options for using the land: to keep it idle or to rent it out (in most cases to managers of the former collective farms). ${ }^{10}$ For example, in 2005, 62.7 percent of all rental contracts were signed with former collective farms (State Agency for Land Resources Newsletter, 18 May, 2005). ${ }^{11}$ Although a sales market started to emerge at about the same time, it did not function well. Poor or non-existing privatization records and unclear transaction procedures were pervasive and numerous cases of land grabbing, manipulation and falsification were recorded (Report of the Ukrainian Parliament Commissioner for Human Rights, 2004).

Figure 3. Changes in Land Ownership Structure

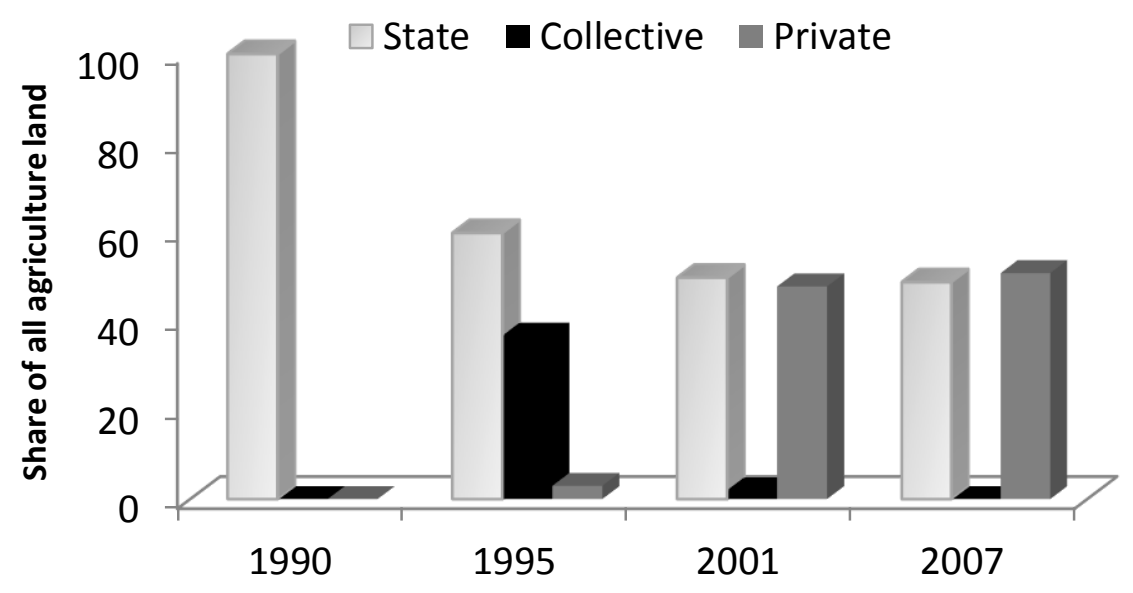

Source: State Agency for Land Resources of Ukraine (2014).

To regulate land use and land transactions, the Parliament of Ukraine adopted a new Land Code in 2001. However, a ban on sales and conversion of agricultural to non- agricultural land (a Moratorium) was imposed until January $1^{\text {st }}, 2005$. The primary motivation for the Moratorium was to provide Government with time to establish proper titles and cadastral records as well as to establish other institutions in support of the land market. The Moratorium has since been

\footnotetext{
${ }^{10}$ In $2005,53.4 \%$ of rental contracts were signed with retirees (State Agency for Land Resources Newsletter, 18 May, 2006). This share was stable over years.

${ }^{11}$ By 2013, this share decreased to 35.5\% (State Agency for Land Resources Newsletter, 1 April, 2013)
} 
extended five times. By 2015, lifting the Moratorium was scheduled for 2016, but likely to be extended again to 2018 or 2020 . Continued extensions were supported by a perceived negative public attitude towards liberalized land sales, technical difficulties in tracing owners of specific land plots, as well as strong lobbies by large producers, local governments and some political parties.

Numerous extensions of the Moratorium contribute to institutional uncertainty in the agricultural sector as rights of tenants, land owners and investors may be changed by future institutional design of the land market. For example, earlier versions of the proposed land market law stipulated constraints on the maximum size of private land holdings, rights to own land by foreigners and legal entities, and maximum size of the rental land. Additional productivitydampening restrictions on land rights include inability to transfer land to more productive uses, limited opportunities to collateralize the assets (reducing access to finance), and decreased incentives to maintain or improve plots (Bellemare 2013).

A more recent example of imposing unexpected restrictions on the land market is the Law of Ukraine adopted by the Parliament on February 12, 2015. This Law imposes seven years as a minimum length of agricultural land rental contracts. Uncertainty in land markets will persist as long as the rules governing the market are not finally settled.

As a response to institutional uncertainty, several coping strategies were observed among the land owners and producers. Among them are informal rental transactions, keeping land idle or short term rental contracts ${ }^{12}$. All these strategies are associated with decline in agricultural productivity and investments, and may also lead to unsustainable land use.

Poor protection of property rights of tenants vs. owners decreases incentives to invest in general and in land improvements in particular as the institutional uncertainty reduces expected net present value of returns on investments. The option value for any investment becomes particularly high, as investors would prefer to have resources available by the time when land sales market is established. In such environment, investments in crop enterprises with relatively short return (e.g. annual crops) would be a safer scenario than investments in crop enterprises with a longer return (e.g. perennials).

\footnotetext{
12 In 2012, about $46 \%$ of all formal rental agreements were for the term of up to 5 years and $85 \%$ were shorter than 10 years (State Agency for Land Resources report, 13 March 2013)
} 
In contrast, in case of equal institutional protection, sales and rental markets produce equal allocation efficiency in the longer run. This paper tests for the difference in the land use patterns between owners and tenants as an evidence for unequal institutional protection using annual data on commercial farms in Ukraine during 2004-2012.

\section{Land Use and Security of Property Rights}

The issue of insecure property rights (e.g. Mathijs and Swinnen, 1998) and the impact of policy on land use switching decisions (e.g. Behan et al., 2006; Engel et al., 2015) is not new to the literature. However, limited empirical evidence is available and there is very little known about this issue in transition countries such as Ukraine. The following analysis of land property rights and decisions between alternative land uses draws on takings literature (e.g. Turnball 2002).

Consider, that a parcel of agricultural land provides a return $(w)$ at different points of time $(t)$, which is a function of investment $(k)$ and a plot-specific random shock to productivity (y) (e.g. infrastructure, soil quality, micro-climate conditions):

$$
\mathrm{w}=\mathrm{W}(\mathrm{k}, \mathrm{t}, \mathrm{y})
$$

For simplicity, we assume that if $\mathrm{k}=0$ the parcel is used for production of annual crops. If $\mathrm{k}>0$ it is switched into production of perennials or other higher value added agricultural production processes (e.g. irrigated crops, green houses). The investment cost includes the investment itself and an opportunity cost. The cost is assumed to be irreversible (in medium term or at a reasonable cost). We also assume that $\mathrm{W}$ is twice differentiable, and $\mathrm{W}_{\mathrm{k}}>0$ (return increases with the investment), and $\mathrm{W}_{\mathrm{kt}}>0$ (return from perennials is increasing faster, e.g. due to the positive elasticity of demand associated with the growing income level).

The net present value (NPV) of returns from an agricultural land plot is (2):

$$
F=\int_{0}^{\infty} \mathrm{W}(\mathrm{k}, \mathrm{t}, \mathrm{y}) e^{-r t} d t
$$

Where ( $\mathrm{r}$ ) is a discount rate.

The decision-maker's problem is to determine when to switch between annual and perennial crops to maximize the NPV of returns from the plot. The switch would be at a point $t_{0}$ 
when an additional rent from perennials would be equal to the rental cost of capital. Thus, the problem can be described in the following form (3):

$$
\max _{t_{0}} F=\int_{0}^{t_{0}} \mathrm{~W}(\mathrm{k}=0, \mathrm{t}, \mathrm{y}) e^{-r t} d t+\int_{t_{0}}^{\infty} \mathrm{W}(\mathrm{k}>0, \mathrm{t}, \mathrm{y}) e^{-r t} d t-K e^{-r t_{0}}
$$

This model shows some interesting features of the optimal switching point:

- The higher is the marginal return on investments $\left(\mathrm{W}_{\mathrm{k}}\right)$ the earlier the switching would take place;

- The higher is the size of investment $(\mathrm{K})$ the later the switching will be.

As was discussed in the previous section, there is a threat to land related rights due to the policy choice - the threat is that the producer may lose control over the investments with probability of $\theta$. Thus, the return to investment should be scaled with a factor $(1-\theta)$. While risk to investments is a common situation of many investment projects, and is normally reflected in the discount rate, the current setup is different. We assume that uncertainty about future land market conditions affects differently tenants vs. own-farm cultivators as discussed below.

Thus, $\mathrm{t}_{0}$ is a function of $\mathrm{W}(\mathrm{k}=0, \mathrm{t}, \mathrm{y}) ; \mathrm{W}(\mathrm{k}>0, \mathrm{t}, \mathrm{y}) ; \mathrm{K}$ and $\theta$. As plot-specific return $y$ is a random variable, $\mathrm{t}_{0}$ would also be a random variable in the population of land parcels $i \in N$. Thus, at any point of time, we would observe parcels at both sides of the switching point. Moreover, in reality, we may not observe the individual parcels but an aggregate of parcels under management of farming entities. Each farm would have $l_{0}$ parcels used for production of annual crops and $l_{1}$ used for perennials. Estimation of the switching point using farm level data (vs. plot level) would require normalization by the farm size $\left(l_{0}+l_{1}\right)$. The resulting dependent variables would be the shares of each type of crop and the inverse of total land size would be on the RHS.

If the property rights of owners and tenants are protected equally, the form of tenure should not affect investment decisions ${ }^{13}$. In contrast, in an environment where the rights of tenants are less protected relative to owners (e.g. in anticipation of Moratorium lifting), we would expect that a larger share of rented land would delay switching decisions. The size of the risk is modeled in our analysis by the share of rented land ${ }^{14}$ (Rent) for producer $i$. Thus, to evaluate the impact of

\footnotetext{
${ }^{13}$ An additional assumption behind this hypothesis is that ownership and tenancy rights provide equal access to financial and other resources (e.g. via collateral). In the Ukrainian environment, this assumption is reasonable as land cannot be used as a collateral.

${ }^{14}$ As the number of parcels subject to risk is $n$, division of both sides of equation by $\left(l_{0}+l_{1}\right)$ is equal to share of rented land.
} 
poor property right protection on investments we test if farmers that operate primarily on rented land have lower share of land parcels with long term investments (e.g into perennial crops).

The resulting empirical model takes the following form (4):

$x_{s i t}=\beta_{0}+\sum_{k=1}^{a} \beta_{1 s} x_{s i(t-k)}+\sum_{k=1}^{a} \beta_{2 s} p_{s(t-k)}+\sum_{k=1}^{a} \beta_{3 s} \operatorname{Rent}_{i(t-k)}+\beta_{4 s} Z_{i t}+\varepsilon_{i s t}$

where $(x)$ stands for share of land of crop (s) (perennial - fruits or annual - grains, or oil crops). This share is explained by the crop prices $(p)$ in previous periods at rayon (district) level (as a proxy for return on investment). Prices are taken in logs. Subscripts $(i)$ and $(t)$ stand for farm and time. The main variable of interest is the share of rented land (Rent) in previous periods (as the decision to invest in a particular crop are made before the current growing season). The estimated effect of rent on share of crops $\left(\beta_{3 \mathrm{~s}}\right)$ is used for hypothesis testing. For an annual crop, only one to three lags may be relevant (as each annual crop participates in crop rotation plans), while for perennials, the decision could have been made several periods ago and thus more lags may be relevant. The number of time lags is driven primarily by the data availability. Specifications with different number of lags were compared. Despite different variables in the model have different number of relevant lags, the main results are robust to the choice of lags and four lags were applied for all RHS variables.

Among other controls $(Z)$, the log of total farm size (in hectares), labor market conditions, dummies for each year and district (rayon) are included.

In addition to the above-mentioned factors, the cost of capital enters the theoretical model (3). We assume that the cost of investments per hectare is the same for all farms and stays unchanged in real terms. It may vary, however, in cross-section, due to variations in access to capital or specific climate and soil conditions. Thus, it is controlled with time invariant regional dummies. Labor market conditions and time dummies provide an additional control for production cost structure. The time lags of the dependent variables $\left(x_{s i(t-k)}\right)$ control for the difference in investment cost among existing and new producers as explained below.

The share of rental land is not, however, a perfect measure of risk factors associated with insecure property rights. As renting in is the only option for expansion of operational land holding in Ukraine, a higher share may also capture various unobservable factors such as access to capital or managerial resources. We assume that these factors will be farm specific rather than crop specific and, thus, would affect all crops in the same way. To identify the effect of insecure 
property rights we test for the difference in the effect of rental land on annual and perennial crops. Thus, the hypothesis for the empirical test is:

$\mathrm{H} 0: \beta 3_{\text {perennial- }} \beta 3_{\text {annual }}=0$

$\mathrm{H} 1: \beta 3_{\text {perennial- }} \beta 3_{\text {annual }}<0$

As all equations are estimated for the same farms, errors are correlated across equations. A seemingly unrelated regression (SUR) modeling approach adds efficiency to estimation of parameters of interest. Errors are clustered at farm level. As each equation includes lags of different sets of dependent variables, the condition for efficiency gain by SUR is satisfied.

The robustness of results is checked by comparing different pairs of annual and perennial crops. We consider perennial, grains and oil seeds and expect that the rental effect will be more negative for perennials than grains or oil seeds.

\section{Data}

The empirical model (4) is estimated using farm-level data the State Statistics Service of Ukraine collected from the universe of commercial farms above 200 ha with Form 50AG for the period 2004-2012. This statistical form is a part of mandatory annual reporting in Ukraine. However, a large number of farms below the reporting threshold also filed the form as it is used as a proof of agricultural activities for export operations by banks and various government agencies and programs. The form is completed based on formal accounting data on inputs and outputs of agricultural production (in most cases generated automatically by accounting software). Thus, the quality of reporting is believed to be high, so there is no issue with selection and previous research (e.g. Deininger and Nizalov 2013) demonstrates that empirical results are comparable to models estimated for other countries. The data were made available for analysis in depersonalized form.

The time period used for analysis is driven by data availability. No data on the land use by crop was collected before 2004. However, most of the agricultural input market liberalization took place after 2002 and thus we capture almost all the period of transformation.

The original data includes 100,464 observations. We restrict the working set to observations with non-missing data on landholding and farms registered outside of cities. The resulting data set includes 76,329 observations (See table 3). The reason for exclusion of "urban" observations is that these cases represent the headquarters of companies which have their operations in different regions and, thus, application of region specific prices and other 
conditions is not appropriate (there are, however, only 3,339 such cases). The final estimation, however, uses only 44,266 observations as several time periods were used for construction of time lags.

Table 3 also shows the distribution of observations across farm sizes. As the category below 200 ha is underrepresented (there are about 40,000 farms below 200 ha in the population, most of them are below 50 ha), we will compare the main results with and without this category and for different size groups separately to test for potential heterogeneity of results.

Table 3. Farm size distribution, number of farms

\begin{tabular}{|l|r|r|r|r|r|r|}
\hline \multicolumn{1}{|c|}{ Year } & 0.1-200 ha & $\mathbf{2 0 0 . 1 - 1 0 0 0}$ & $\begin{array}{c}\text { 1000.1- } \\
\mathbf{2 0 0 0}\end{array}$ & $\begin{array}{c}\text { 2000.1- } \\
\mathbf{5 0 0 0}\end{array}$ & $\begin{array}{c}\text { Above 5000.1 } \\
\text { ha }\end{array}$ & Total \\
\hline 2004 & 508 & 2,674 & 2,851 & 2,676 & 453 & $\mathbf{9 , 1 6 2}$ \\
\hline 2012 & 574 & 2,808 & 2,297 & 2,067 & 614 & $\mathbf{8 , 3 6 0}$ \\
\hline Total 2004-2012 & 5,576 & 23,530 & 21,986 & 20,414 & 4,823 & $\mathbf{7 6 , 3 2 9}$ \\
\hline
\end{tabular}

Source: State Statistics Service (Form 50AG) for universe of medium and large farms

The main variables of interest are the share of annual vs. perennial crops and the share of rented land. Table 4 presents a summary of these variables with respect to farm size for 2004 and 2012. The annual crops are represented by grains and oil crops. The average share of perennial crops declined for all but the smallest farms while the share of annual crops increased universally. The only exception is the decrease in grains for the smallest farms. Regarding the share of rented land, it increased for all farms, but the rate of increase differs across the size groups. The largest increase was for the farms above 5,000 ha, which reflects the expansion of very large farms over this period (see Deininger and Nizalov (2013) for further discussion).

Table 4. Crop mix by farm size (\% of total crop area)

\begin{tabular}{l|ccccccc}
\multicolumn{1}{c|}{ Crop } & \multicolumn{1}{c}{$\begin{array}{c}\mathbf{0 . 1 - 2 0 0} \\
\text { Year }\end{array}$} & $\begin{array}{c}\mathbf{2 0 0 . 1 -} \\
\mathbf{1 0 0 0}\end{array}$ & $\begin{array}{c}\mathbf{1 0 0 0 . 1 -} \\
\mathbf{2 0 0 0}\end{array}$ & $\begin{array}{c}\mathbf{2 0 0 0 . 1 -} \\
\mathbf{5 0 0 0}\end{array}$ & $\begin{array}{c}\text { Above 5000.1 } \\
\text { ha }\end{array}$ & Total \\
\hline \multirow{2}{*}{ Perennials, \% } & 2004 & 1.06 & 0.94 & 0.68 & 0.35 & 0.19 & 0.66 \\
& 2012 & 1.96 & 0.68 & 0.24 & 0.16 & 0.09 & 0.48 \\
\hline \multirow{2}{*}{ Oil crops, \% } & 2004 & 2.03 & 4.63 & 7.81 & 11.93 & 13.69 & 8.05 \\
& 2012 & 8.11 & 25.54 & 27.45 & 27.04 & 26.48 & 25.31 \\
\hline \multirow{2}{*}{ Grains, \% } & 2004 & 46.56 & 48.97 & 46.18 & 45.51 & 45.25 & 46.77 \\
& 2012 & 37.83 & 47.75 & 49.57 & 46.88 & 49.18 & 47.46 \\
\hline \multirow{2}{*}{ Rented land, \% } & 2004 & 86.25 & 94.15 & 94.49 & 92.28 & 87.95 & 92.96 \\
& 2012 & 87.37 & 94.49 & 95.90 & 94.81 & 93.33 & 94.38
\end{tabular}

Source: State Statistics Service (Form 50AG) for universe of medium and large farms 
One feature of crop mix patterns relevant to the current analysis is the specialization in crop production observed among the farms. As presented in Table 5, a large share of farms are not involved in production of some of the selected crops. For example, 93 percent of farms are not involved in production of perennials and 28 percent of farms are not producing oil crops. On the other hand, there are farms that grow only one of the crops. This distribution pattern has important implications for empirical analysis and interpretation. First, OLS may underestimate the effect of insecure property rights as the distribution is censored. Thus, a Tobit model is used and compared with OLS. Second, the cost of land conversion is likely to be lower for those already involved with production of a particular crop than for those who are not. This cost is related to the fixed cost of acquiring know-how, infrastructure, equipment, marketing etc. that a farmer has to cover when starting a new crop enterprise. Thus, this difference in cost of investment has to be controlled. A time lag of the dependent variable will be used for this purpose. Table 6 shows that unlike the dynamics of perennial crop share for the whole sample, the share of this crop among producers was increasing. This increase, however, was smaller for larger producers and correlates negatively with a larger increase in rental share.

Table 5. Farms with extreme shares of crop

\begin{tabular}{|l|c|c|}
\hline & $\begin{array}{c}\text { Share of non-producers } \\
\text { (crop share }=0 \%)\end{array}$ & $\begin{array}{c}\text { Share of specialized producers } \\
\text { (crop share = 100\%) }\end{array}$ \\
\hline Perennials & $93.15 \%$ & $0.02 \%$ \\
\hline Grains & $6.14 \%$ & $2.19 \%$ \\
\hline Oil crops & $28.10 \%$ & $0.31 \%$ \\
\hline
\end{tabular}

Source: State Statistics Service (Form 50AG) for universe of medium and large farms

Table 6. Share of land under perennial, grain and oil crops among existing crop producers.

\begin{tabular}{|c|c|c|c|c|c|c|}
\hline & 0 ha & 200.1-1000 & $\begin{array}{l}1000.1- \\
2000\end{array}$ & $\begin{array}{l}2000.1- \\
5000 \\
\end{array}$ & $\begin{array}{l}\text { Above 5000.1 } \\
\text { ha }\end{array}$ & Total \\
\hline Peren & & & & & & \\
\hline 2004 & 23.94 & 9.36 & 6.15 & 2.45 & 0.93 & 3.23 \\
\hline 2012 & 41.99 & 16.16 & 6.47 & 2.70 & 0.61 & 2.65 \\
\hline Oil cr & & & & & & \\
\hline 2004 & 21.64 & 12.04 & 12.34 & 13.88 & 14.77 & 13.69 \\
\hline 2012 & 40.19 & 33.06 & 30.40 & 28.75 & 26.32 & 28.51 \\
\hline Grain & & & & & & \\
\hline 2004 & 61.01 & 49.46 & 46.63 & 45.47 & 46.36 & 46.33 \\
\hline 2012 & 64.74 & 50.83 & 50.71 & 47.47 & 50.07 & 49.33 \\
\hline
\end{tabular}

Source: State Statistics Service (Form 50AG) for universe of medium and large farms 
As discussed in the previous section, controls for crop prices and labor market conditions were included as proxies for return to investments and region specific cost of investment. These variables are measured at district (rayon) level. Descriptive statistics of these variables is presented in Annex (Table A1). The natural logarithm of prices, wage and land area is used for estimation. One, two, three and four year lags of all control variables are used in all specifications.

\section{Results}

A system of three equations was estimated. A summary of results is presented in Table 7 (Details can be found in Annex, Table A2). The shares of perennials, grains and oil crops are the dependent variables and the SUR model is used to adjust for the correlation in error terms across equations. Columns 1-3 present results of the OLS estimation. We can clearly see the difference between the effects of rental share on the outcomes between perennial and annual crops. The estimates on lags of rental share represent a short-run effect. The total short-run effect on share of perennial crops is not significant. For grain and oil crops, the total short-run effect is 0.064 and 0.029 respectively (significant in both cases). To test the hypothesis about insecure rental rights, the difference between the total short-run effects on perennial and annual crops is estimated. As presented in Panel B of Table 7 the difference between the effect on perennial and grain crops is -.065 points, which means that a one percentage point higher share of rented land would decrease the share of perennial crops by 0.065 percentage points over the course of four years (in the short run) controlling for farm size, prices and rayon and year-specific unobservable factors. The difference between the perennials and oil crops is -.03. This difference is statistically significant and the effect on perennials is more negative, supporting the hypothesis about insecure property rights of the tenants (perceived or actual). There is also some difference between the annual crops, implying that rented land is used primarily for grain production (vs. oil).

It is reasonable to expect that the response of investments into perennial crops to insecure rental rights is distributed over a longer period of time. A Koyck multiplier (assuming a geometrical distribution of time lags) is used for approximation of the long run effect. As reported in Table 7, the long run difference between the response of perennial and grains is - 
0.218 , while for the oil crops this difference is -0.118 (significant in both cases). The long run effect is almost four times larger than the short run effect.

Yet, as discussed earlier, OLS would underestimate the effect of interest, as a substantial share of observations is censored. Columns 4-6 present marginal effects from Tobit model. The difference in short-run effect for perennial-grains and perennial-oils are -0.108 and -0.081 points respectively and are significant. The values are a bit larger than in OLS, but are of comparable magnitude. The long run effect, however, cannot be estimated precisely using the Koyck approximation as the sum of lags of the dependent variable (LHS) for perennial crops is greater than one. Thus the estimated difference between the crops can be treated as a lower bound of long-run effect. The long-run effect is found to be -0.152 for perennial vs. grains and -0.054 for perennial vs. oil crops. In both cases, the estimates of the long-run effect are below the OLS estimates.

Finally, we restrict the sample to farms above 200 ha and re-estimate the Tobit model (Columns 7-9). The short-run effect of rented share is -0.094 and -0.069 points for perennial vs. grains and perennials vs. oil crops respectively. The estimates are slightly lower than those for the full sample, but the magnitude is similar. This difference in results may suggest that the excluded group of farms below 200 ha are affected more negatively by insecure property rights.

The result implies that farmers rent additional plots of land primarily for production of more secure annual crops while being reluctant to invest in perennials on the rented plots despite their higher profitability. Such preferences lead to overall underinvestment in crops that are higher value added, but more capital intensive. In turn, it leads to less efficient allocation of land.

To assess the practical significance of the estimated results, we compare the estimated effect with the observed changes in the share of perennial crops. As was estimated by the Tobit model (Columns 4-6), the short-run perennial-grain and perennial-oil crop differences are -0.108 and 0.081 points respectively (the average is about -.095 points decrease in the share of perennial crop for every one percentage point increase in the share of rented land over the four year period). If we multiply this average effect by the actual increase in rental share between 2004 and 2012 (1.42 percentage points, see Table 1), then the expected change in the share of perennial crops is about -0.135 percentage points. In fact, this estimate is 75 percent of the observed change in the share of perennials between 2004 and 2012, which was -0.18 percentage point (Table 1). 
The long-run effect (as estimated by OLS) is at least -0.168 (average between perennialgrains and perennial-oils). Thus, the increase in rental share by 1.42 percentage point has contributed a 0.239 percentage points decrease in the share of land used for perennial crop production. We can conclude that the decrease in the observed investment in perennial crops (and likely other long term investments in land quality and other agricultural projects) is largely explained by the insecurity of property rights of tenants associated with land reform in Ukraine.

How much does this loss cost the country? If we estimate the losses as the difference in value added per hectare between perennials and the highest alternative among the annual crops (oil seeds) - profitability in 2012 was 1,772.87 and 774.25 USD per ha respectively (Table 2) then the loss is about 1,000 USD per hectare. Over 2004-2012 period Ukraine lost about 43 thousand hectares of perennials, which we can now attribute to insecure property rights. It implies that Ukraine loses about 43M USD per year of value added on under-investments in perennial crops only. Underinvestment in dairy, vegetables, greenhouses and irrigation would increase the size of these losses further. This loss is distributed differently across the farm sizes as the change in the rental share was different (Table 4) and larger farms are less sensitive to insecure rights as presented below.

The difference between the estimation results for the sample of farms above 200 ha and unrestricted sample (columns 4, 5 and 6 vs. 7, 8 and 9) suggests that the effect of insecure property rights may vary across farm size. To explore this possible heterogeneity further, the Tobit model was estimated separately for categories of different farm sizes. Figures 4, 5 and 6 illustrate the summary of estimated results. Details are presented in Annex, Table A3.

Figure 4 shows that the negative effect of rental share on perennial crops is strongest for the smallest farms (below $200 \mathrm{ha}$ ) ${ }^{15}$. The negative effect disappears for farms above 5,000 ha suggesting that large farms are better protected than small.

\footnotetext{
${ }^{15}$ The difference between the smallest farms (base category) and other farm size groups is statistically significant. Test results are available upon request.
} 
Figure 4. Effect of rent share on share of perennial crops

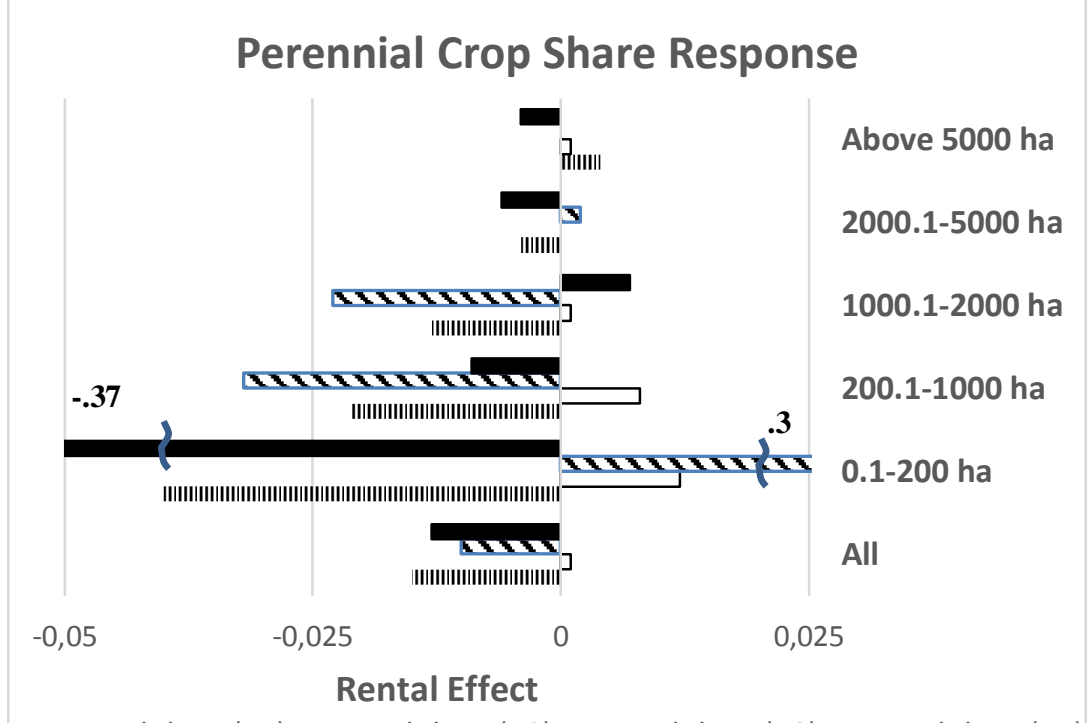

As can be inferred from Figures 5 and 6, the difference in rental effect between perennial and annual crops is magnified by strong positive associations of rent and share of annual crops for the smallest farms. Such differentials in the effect of property rights might possibly be explained by the market and political power enjoyed by larger farms.

Figure 5. Effect of rent share on share of grain crops

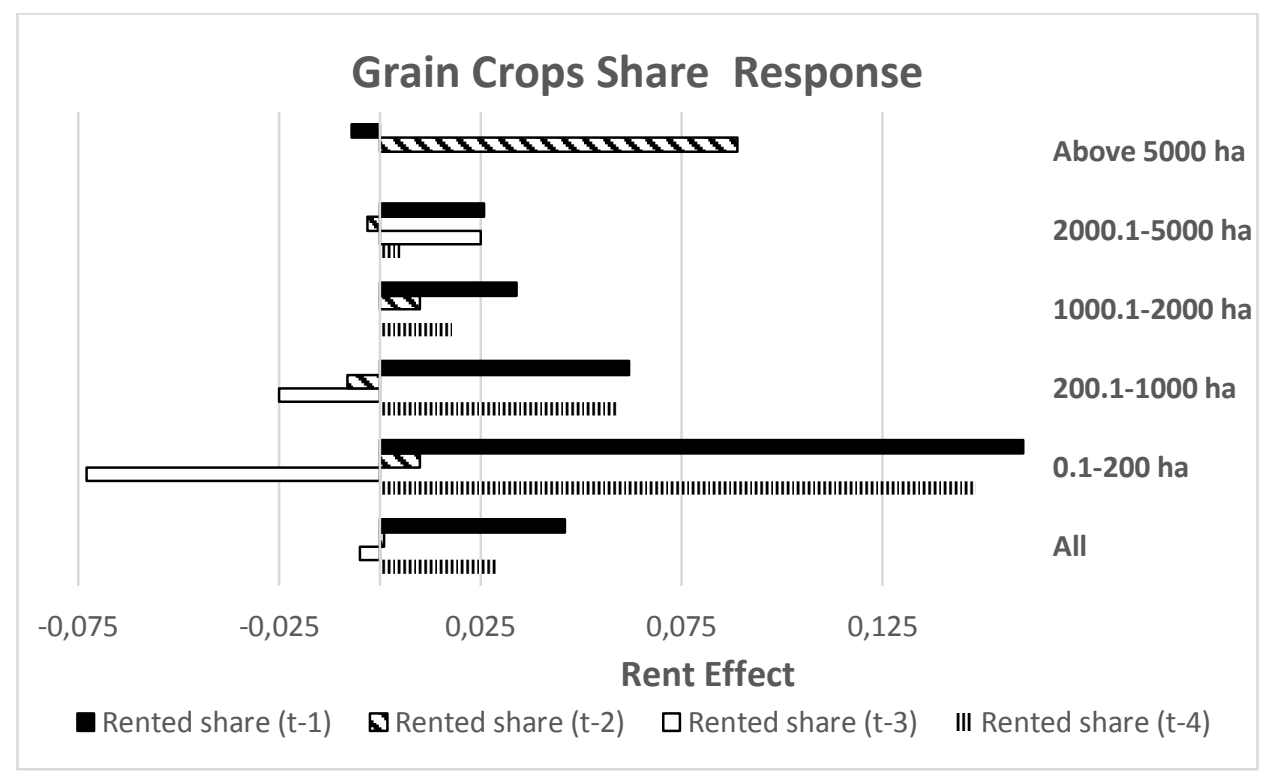


Figure 6. Effect of rent share on share of oil crops

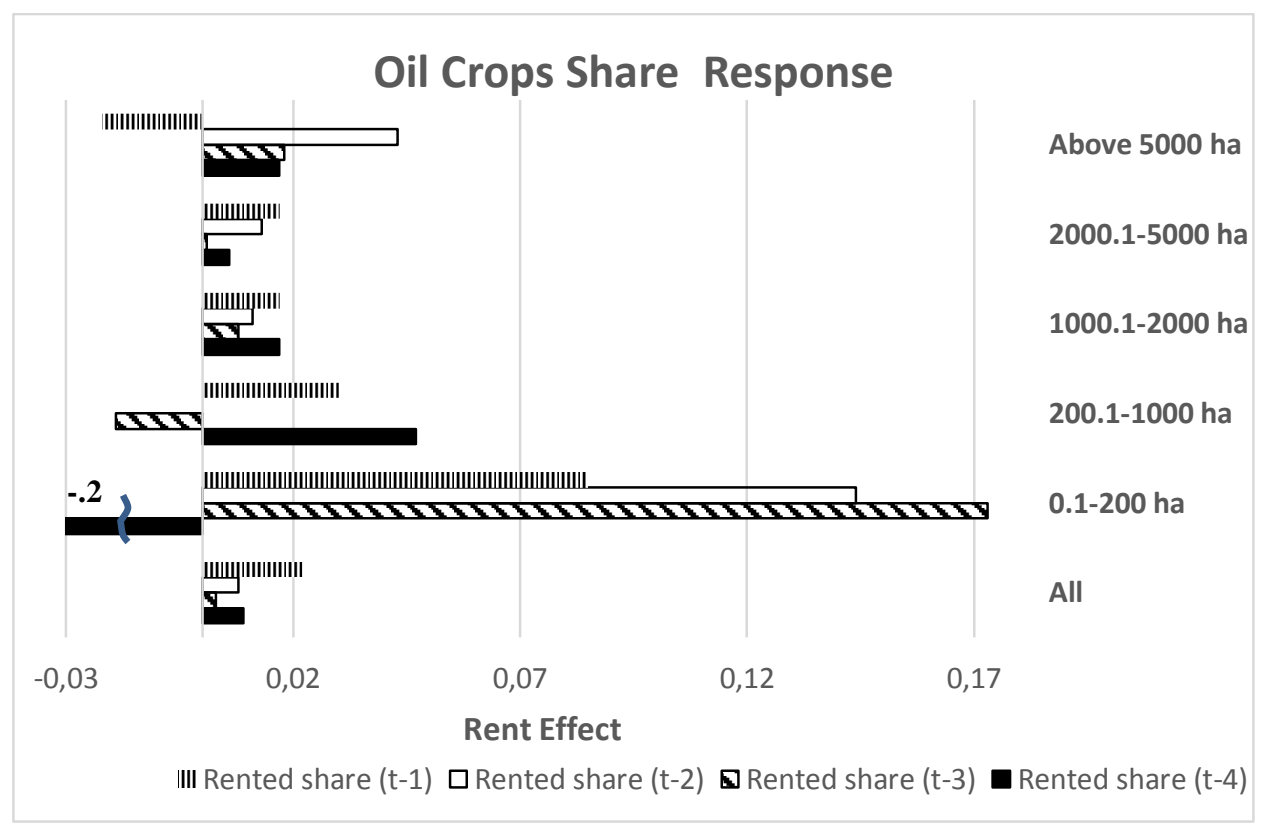

The total difference between the short-run effects for perennials and grains is largest for farms below 200ha (-0.338) and smallest for the farms cultivating between 2,000 ha and 5,000 ha (-0.062), and is significant in all cases (Table A3, Panel D). A similar pattern is observed for perennial vs. oil crops.

An additional support to this conclusion can be derived from Figure 7, which shows profitability of different crops for farms of different size categories. The figure shows that the farms below 2,000 ha have higher profitability of perennial crop production. Insecure rights are the most likely cause that prevents them from adjusting their crop mix to equalize return across different crop enterprises.

One may argue that the observed difference across the farm sizes may reflect the difference in access to capital. While the difference in capital access is documented, such difference should affect equally all crops and should not be related to the form of land tenure. As the market for land does not exist, land cannot be used as collateral. On the other hand, larger farms could have better access to legal services and protection, which would support the property rights story. Field observations by authors confirm this conclusion. In order to deal with imperfect system of registration of rental rights, large farms keep on average one legal staff person per 1,000 hectares whose assignment is to deal with land rental issues. It implies that farms below 1,000 ha cannot afford the same level of legal protection as larger farms and may shift to a less risky production of annual crops. 


\section{Figure 7. Profit by crop by farm size}

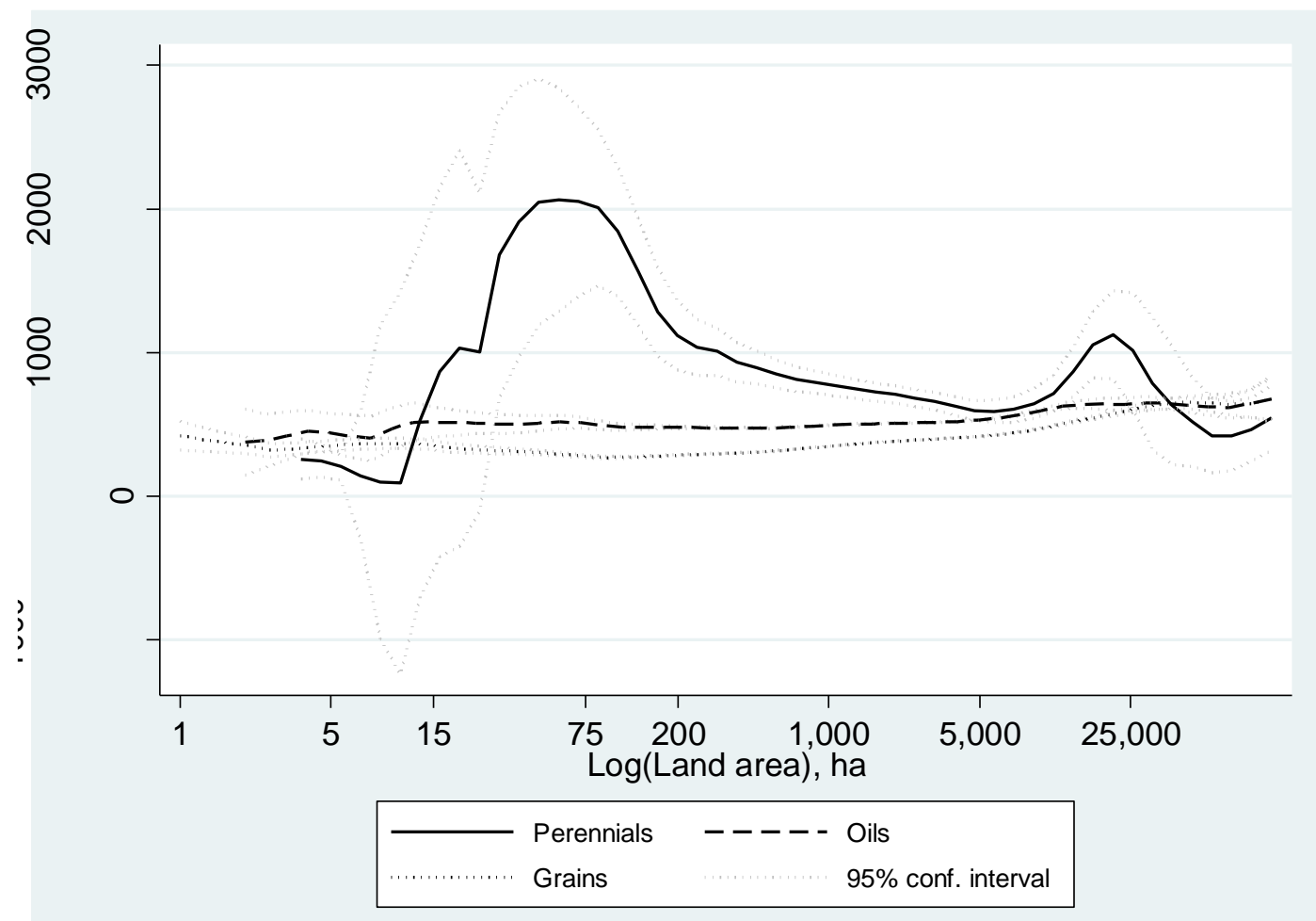

\section{Conclusions}

To conclude, the case of Ukraine shows that privatization of assets is not enough, by itself, to improve market performance. Institutional reforms that reduce uncertainty and improve protection of rights are also a pre-condition for economic productivity gains (Zinnes, Eilat and Sachs, 2001; Place, 2009). While privatization of land titles was implemented through Ukraine by the mid-2000s, uncertainty remains over how and when full land use and transfer rights will be established.

The results of current analysis show that uncertainty and poor protection of tenants' rights leads to underinvestment in crops with long investment cycle and higher value added. As a result, tenants deviate from optimal crop mix, reducing productivity of tenant farms. Taking into account that about 95 percent of agricultural land is rented in 2012, Ukraine faces significant losses in agricultural production and GDP in the short run. Also, the uncertainty leads to underinvestment in new technologies, including adaptation to climate change. 
The moratorium on land sales that has persisted for more than 15 years has detrimental consequences for Ukrainian agriculture. The level of technological development of several industries in Ukraine such as production and processing of fruit and vegetables, livestock production, dairy, and irrigated crop production is lagging behind grain production. Production of annual crops may suffer from the same problem, but to a lesser extent, as underinvestment in soil fertility is likely to take place as well. Ukraine loses not only a substantial share of current GDP, but also an opportunity to have higher productivity growth over the next 5-7 years due to a long-run effect of insecure rights.

The remedies for this uncertainty are primarily of political nature. Adoption of the land market law and lifting the Moratorium on land sales could finally provide certainty about the rights of owners, tenants, state and investors. Together with improvements in rental right registration procedures, better law enforcement and decrease in corruption, this law should provide a long needed incentives for development of Ukrainian agriculture and rural areas. Finally, resolving uncertainty regarding the land market would stimulate longer-term lease agreements and make investment incentives for tenant farms more similar to those for owner farms.

The implications of this study go far beyond the agriculture and Ukraine. It provides evidence that relatively low level of property rights protection diverts investors from entire industries and geographic regions. The example of Ukraine shows that despite its fertile soil and good climate, Ukrainian agriculture remains less productive than its European counterparts and the inflow of investments to agriculture is much lower than to other industries in Ukraine. The risks of civil disturbances, wars, nationalizations and other forceful withdrawals of property rights may have long-lasting consequences for agricultural productivity, crop mix and investments.

\section{Literature}

Acemoglu, Daron, Simon Johnson, and James A. Robinson. 2001. "The Colonial Origins of Comparative Development: An Empirical Investigation." American Economic Review 91 (5):1369-1401.

Agricultural Sector in Ukraine. NIKO: Kyiv, 2011

Baumann, Matthias, Tobias Kuemmerle, Marine Elbakidze, Mutlu Ozdogan, Volker C. Radeloff, Nicholas S. Keuler, Alexander V. Prishchepov, Ivan Kruhlov, and Patrick Hostert (2011). 
Patterns and drivers of post-socialist farmland abandonment in Western Ukraine Land Use Policy 28: 552-562.

Behan, Jasmina, Kieran McQuinn, and Maurice J. Roche (2006). Rural Land Use: Traditional Agriculture or Forestry? Land Economics 82(1): 112-123.

Bellemare, Marc F. (2013) The Productivity Impacts of Formal and Informal Land Rights: Evidence from Madagascar Land Economics 89(2): 272-290.

Bezlepkina, I., van Berkum, S., and Rau, M. (2013) Prospects for Ukraine's agrifood sector: Implications for Dutch trade relations. LEI report 2013-045, Wageningen, Netherlands.

Constitution of the Ukrainian SSR (1978)

Constitution of Ukraine (1997)

Court of Auditors of Ukraine (2010) Land Gambit. Press Release of the Court of Auditors of Ukraine as of 09 Nov 2010.

Deininger, Klaus and Denys Nizalov (2013). Are mega-farms the future of global agriculture? Exploring the farm size-productivity relationship for large commercial farms in Ukraine - World Bank Policy Research working paper WPS 6544/ Kyiv School of Economics discussion paper \# 49

Engel, Stefanie, Charles Palmer, Luca Taschini, and Simon Urech (2015) Conservation Payments Under Uncertainty, Land Economics 91(1): 36-56.

Food and Agriculture Organization of the United Nations. Publicly available at http://faostat.fao.org

Food Outlook. Global Markets Analysis. Food and Agriculture Organization of the United Nations, 2010.

Gollin, Douglas, David Lagakos and Michael E. Waugh (2014). The Agricultural Productivity Gap, The Quarterly Journal of Economics, 129 (2): 939-993.

Hall, Robert E. and Charles I. Jones. 1999. "Why Do Some Countries Produce So Much More Output perWorker than Others?” Quarterly Journal of Economics 114 (1):83-116.

Hsieh, Chang-Tai and Peter J. Klenow. 2009. "Misallocation and Manufacturing TFP in China and India." Quarterly Journal of Economics 124:1403-1448.

Lerman, Z., D. Sedik, N. Pugachev and A. Goncharuk (2006). Rethinking Agricultural Reform in Ukraine. FAO, Rome.

Lewis, W.A. 1955. The Theory of Economic Growth. Irwin. 
Mathijs, E. and J.F.M. Swinnen (1998). The economics of agricultural decollectivization in East Central Europe and the former Soviet Union, Economic Development and Cultural Change, 47:126.

Nizalov, Denys, Suzanne Thornsbury, Scott Loveridge, Mollie Woods, and Olha Zadorozhna (2015). "Dynamics of Agricultural Production and Land Use in Post-Soviet Ukraine ," (Chapter 21 in "The Emerging Role of KRU in Global Agricultural Markets: Promise and Concern", eds. Andy Schmitz and Willie Meyers), CABI.

Qineti, Artan, Miroslava Rajcaniova, Kustrim Braha, Pavel Ciaian, and Jona Demaj (2014) "When land markets do not work and status-quo agrarian structures persist: A case study from rural Albania" Poster paper prepared for the EAAE 2014 Congress, Ljubljana, Slovenia, August.

Place, Frank (2009). Land Tenure and Agricultural Productivity in Africa: A Comparative Analysis of The Economics Literature and Recent Policy Strategies and Reforms. World Development, 37(8): 1326-36.

Restuccia, Diego and Richard Rogerson. 2008. "Policy Distortions and Aggregate Productivity with Heterogeneous Establishments.” Review of Economic Dynamics 11 (4):707-720.

Rosenstein-Rodan, P.N. 1943. "Problems of Industrialisation of Eastern and South-Eastern Europe.” The Economic Journal 53 (210):202-211.

Rostow, W.W. 1960. The Stages of Economic Growth: A Non-Communist Manifesto. Cambridge, Cambridge University Press.

Roth M, Valletta W. (2006) Land Reform and Land Market Development in Ukraine. USAID Report (June).

Shmorhun, J. Agriculture in Ukraine: Build-up: a flexible and reliable approach. USUBC: Washington, 2009

State Agency for Land Resources of Ukraine (2014). Available at: http://land.gov.ua/en. (accessed 27 February 2014).

State Statistics Committee (2011). Statistical Yearbook of Ukraine 2010.

State Statistics Committee (2013). Statistical Yearbook of Ukraine 2012.

State Statistics Committee (2012). Socio-Demographic Characteristics of Ukrainian Hoouseholds in 2012 (results of Household Budget Survey).

Turnbull, Geoffrey K. (2002). Land Development under the Threat of Taking, Southern Economic Journal, Vol. 69, No. 2, pp. 290-308

Ukraine Agricultural Competitiveness. Word Bank Report: Washington, 2008 
Ukrainian Parliament Commissioner for Human Rights (2004) Property rights of Ukrainian citizens for land. Report of the Commissioner 2004. Available online:

http://www.ombudsman.kiev.ua/Dop_3/d3_zm.htm

Ukrainian Parliament Commissioner for Human Rights (2008) Property rights of Ukrainian citizens for land. Report of the Commissioner 2008. Available online:

http://ombudsman.kiev.ua/dopovid_5/d_05_4_3.htm

Ukrainian Parliament Commissioner for Human Rights (2010) Property rights of Ukrainian citizens for land. Report of the Commissioner 2010. Available online:

http://www.ombudsman.kiev.ua/dopovid_6/d_06_3_5.htm

United Nations Educational, Scientific and Cultural Organization (UNESCO). 2009. Institute for Statistics. Available online: http://www.indexmundi.com/facts/ukraine/literacy-rate

United Nations. n.d. Country Profile: Ukraine. Department of Economic and Social Affairs, Population Division, Population Estimates and Projections Section. Accessible at:

http://esa.un.org/unpd/wpp/country-profiles/country-profiles 1.htm

Zinnes, Clifford, Yair Eilat, and Jeffrey Sachs (2001) "The Gains from Privatization in

Transition Economies: Is ‘Change of Ownership' Enough” IMF Staff Papers, Vol 48, 146-170. 


\section{Annex}

Table A.1. Control variables

\begin{tabular}{|l|l|l|l|r|r|r|}
\hline Variable & \multicolumn{1}{l}{ Year } & Obs. & \multicolumn{1}{l}{ Mean } & Std. Dev. & \multicolumn{1}{l|}{ Min. } & \multicolumn{1}{l|}{ Max. } \\
\hline Perennial Price, USD/mt & 2004 & 9162 & 163.09 & 113.87 & 11.74 & 723.23 \\
\cline { 2 - 7 } & 2012 & 8206 & 317.35 & 202.84 & 12.07 & 1416.53 \\
\hline Oil Crop Price, USD/mt & 2004 & 9162 & 310.79 & 257.54 & 67.15 & 5335.98 \\
\cline { 2 - 7 } & 2012 & 8360 & 433.48 & 50.69 & 261.49 & 1499.98 \\
\hline Grain Price, USD/mt & 2004 & 9162 & 130.16 & 18.39 & 92.86 & 263.58 \\
\cline { 2 - 7 } & 2012 & 8360 & 185.83 & 14.74 & 137.67 & 471.25 \\
\hline Wage, UAH/month & 2004 & 9162 & 370.58 & 82.44 & 242.00 & 876.00 \\
\cline { 2 - 7 } & 2012 & 7889 & 1949.93 & 424.55 & 480.00 & 5073.00 \\
\hline Unemployment, \% & 2004 & 9162 & 5.91 & 3.02 & 0.70 & 16.80 \\
\cline { 2 - 7 } & 2012 & 7867 & 3.12 & 1.71 & 0.20 & 9.00 \\
\hline Farm size, ha & 2004 & 9162 & $1,881.54$ & $2,022.61$ & 1.00 & $91,121.00$ \\
\cline { 2 - 7 } & 2012 & 8360 & $2,048.17$ & $3,383.94$ & 1.00 & $111,712.00$ \\
\hline
\end{tabular}


Table A.2. Share of perennial, grain and oil crops

\begin{tabular}{|c|c|c|c|c|c|c|c|c|c|}
\hline \multirow[b]{2}{*}{ VARIABLES } & \multicolumn{3}{|c|}{ OLS } & \multicolumn{3}{|c|}{ Tobit, all } & \multicolumn{3}{|c|}{ Tobit, above 200 ha } \\
\hline & Perennial share & Grain share & Oil share & $\begin{array}{c}\text { Perennial } \\
\text { share }\end{array}$ & Grain share & Oil share & $\begin{array}{c}\text { Perennial } \\
\text { share }\end{array}$ & $\begin{array}{l}\text { Grain } \\
\text { share }\end{array}$ & Oil share \\
\hline & $(1)$ & (2) & (3) & $(4)$ & $(5)$ & (6) & $(7)$ & $(8)$ & (9) \\
\hline Dependent (t-1) & $\begin{array}{c}0.892 * * * \\
(0.037)\end{array}$ & $\begin{array}{c}0.409 * * * \\
(0.008)\end{array}$ & $\begin{array}{c}0.398 * * * \\
(0.013)\end{array}$ & $\begin{array}{c}1.161 * * * \\
(0.043)\end{array}$ & $\begin{array}{c}0.435^{* * *} \\
(0.009)\end{array}$ & $\begin{array}{c}0.457 * * * \\
(0.014)\end{array}$ & $\begin{array}{c}1.049 * * * \\
(0.035)\end{array}$ & $\begin{array}{c}0.430 * * * \\
(0.008)\end{array}$ & $\begin{array}{c}0.473 * * * \\
(0.012)\end{array}$ \\
\hline Dependent (t-2) & $\begin{array}{c}0.030 \\
(0.038)\end{array}$ & $\begin{array}{c}0.141^{* * * *} \\
(0.009)\end{array}$ & $\begin{array}{c}0.198 * * * \\
(0.014)\end{array}$ & $\begin{array}{c}0.060 \\
(0.048)\end{array}$ & $\begin{array}{c}0.153 * * * \\
(0.010)\end{array}$ & $\begin{array}{c}0.205^{* * *} \\
(0.016)\end{array}$ & $\begin{array}{c}0.064 \\
(0.053)\end{array}$ & $\begin{array}{c}0.131 * * * \\
(0.009)\end{array}$ & $\begin{array}{c}0.194 * * * \\
(0.014)\end{array}$ \\
\hline Dependent $(\mathrm{t}-3)$ & $\begin{array}{c}0.047 \\
(0.034)\end{array}$ & $\begin{array}{c}0.073 * * * \\
(0.008)\end{array}$ & $\begin{array}{c}0.048 * * * \\
(0.012)\end{array}$ & $\begin{array}{l}0.089 * \\
(0.053)\end{array}$ & $\begin{array}{c}0.081 * * * \\
(0.009)\end{array}$ & $\begin{array}{c}0.032 * * \\
(0.014)\end{array}$ & $\begin{array}{c}0.122 * * \\
(0.056)\end{array}$ & $\begin{array}{c}0.077 * * * \\
(0.008)\end{array}$ & $\begin{array}{c}0.032 * * \\
(0.013)\end{array}$ \\
\hline Dependent (t-4) & $\begin{array}{c}-0.011 \\
(0.037)\end{array}$ & $\begin{array}{c}0.052 * * * \\
(0.008)\end{array}$ & $\begin{array}{c}0.053 * * * \\
(0.011)\end{array}$ & $\begin{array}{c}0.058 \\
(0.057) \\
\end{array}$ & $\begin{array}{c}0.057 * * * \\
(0.008)\end{array}$ & $\begin{array}{c}0.029 * * \\
(0.013)\end{array}$ & $\begin{array}{c}0.002 \\
(0.051)\end{array}$ & $\begin{array}{c}0.055^{* * *} * \\
(0.008)\end{array}$ & $\begin{array}{c}0.025 * * \\
(0.011)\end{array}$ \\
\hline Log(Land area) & $\begin{array}{c}-0.049 * * * \\
(0.011)\end{array}$ & $\begin{array}{l}-0.061 \\
(0.109)\end{array}$ & $\begin{array}{c}0.477 * * * \\
(0.067)\end{array}$ & $\begin{array}{c}1.294 * * * \\
(0.116)\end{array}$ & $\begin{array}{l}0.214^{*} \\
(0.125)\end{array}$ & $\begin{array}{c}2.112 * * * \\
(0.106)\end{array}$ & $\begin{array}{c}0.876^{* * *} * \\
(0.138)\end{array}$ & $\begin{array}{c}-0.362^{* *} \\
(0.167)\end{array}$ & $\begin{array}{c}1.957 * * * \\
(0.140)\end{array}$ \\
\hline $\log ($ Land area $)$ squared & $\begin{array}{l}0.014 * \\
(0.008)\end{array}$ & $\begin{array}{c}-0.199 * * * \\
(0.044)\end{array}$ & $\begin{array}{c}-0.117 * * * \\
(0.020)\end{array}$ & $\begin{array}{c}0.200 * * * \\
(0.033)\end{array}$ & $\begin{array}{c}-0.375 * * * \\
(0.063)\end{array}$ & $\begin{array}{c}-0.672 * * * \\
(0.059)\end{array}$ & $\begin{array}{c}0.140 * * \\
(0.069)\end{array}$ & $\begin{array}{c}0.233 * * \\
(0.095)\end{array}$ & $\begin{array}{c}-0.614 * * * \\
(0.075)\end{array}$ \\
\hline Rented share (t-1) & $\begin{array}{c}0.000 \\
(0.002)\end{array}$ & $\begin{array}{c}0.042 * * * \\
(0.009)\end{array}$ & $\begin{array}{c}0.014 * * \\
(0.006)\end{array}$ & $\begin{array}{c}-0.013 \\
(0.008)\end{array}$ & $\begin{array}{c}0.046^{* * * *} \\
(0.011)\end{array}$ & $\begin{array}{c}0.022 * * * \\
(0.008)\end{array}$ & $\begin{array}{l}-0.005 \\
(0.007)\end{array}$ & $\begin{array}{c}0.041 * * * \\
(0.009)\end{array}$ & $\begin{array}{c}0.020 * * * \\
(0.008)\end{array}$ \\
\hline Rented share (t-2) & $\begin{array}{c}-0.000 \\
(0.002)\end{array}$ & $\begin{array}{c}0.001 \\
(0.011)\end{array}$ & $\begin{array}{c}0.004 \\
(0.005)\end{array}$ & $\begin{array}{c}-0.010 \\
(0.008)\end{array}$ & $\begin{array}{c}0.001 \\
(0.012)\end{array}$ & $\begin{array}{c}0.008 \\
(0.008)\end{array}$ & $\begin{array}{c}-0.012 * \\
(0.007)\end{array}$ & $\begin{array}{c}0.005 \\
(0.010)\end{array}$ & $\begin{array}{c}0.008 \\
(0.008)\end{array}$ \\
\hline Rented share (t-3) & $\begin{array}{c}0.000 \\
(0.001)\end{array}$ & $\begin{array}{l}-0.005 \\
(0.010)\end{array}$ & $\begin{array}{c}0.005 \\
(0.004)\end{array}$ & $\begin{array}{c}0.001 \\
(0.006)\end{array}$ & $\begin{array}{l}-0.005 \\
(0.011)\end{array}$ & $\begin{array}{c}0.003 \\
(0.007)\end{array}$ & $\begin{array}{c}0.001 \\
(0.005)\end{array}$ & $\begin{array}{l}-0.002 \\
(0.009)\end{array}$ & $\begin{array}{c}0.001 \\
(0.006)\end{array}$ \\
\hline Rented share (t-4) & $\begin{array}{c}-0.001 \\
(0.001)\end{array}$ & $\begin{array}{c}0.025^{* * *} * \\
(0.007)\end{array}$ & $\begin{array}{c}0.007 * * \\
(0.003)\end{array}$ & $\begin{array}{c}-0.015 * * * \\
(0.004)\end{array}$ & $\begin{array}{c}0.029 * * * \\
(0.008)\end{array}$ & $\begin{array}{l}0.009 * \\
(0.005)\end{array}$ & $\begin{array}{c}-0.010 * * * \\
(0.004)\end{array}$ & $\begin{array}{c}0.023 * * * \\
(0.007)\end{array}$ & $\begin{array}{c}0.012 * * * \\
(0.004)\end{array}$ \\
\hline Log(Price Perennials) (t-1) & $\begin{array}{c}0.058 * * * \\
(0.022)\end{array}$ & $\begin{array}{c}0.466 * * \\
(0.184)\end{array}$ & $\begin{array}{c}0.170 \\
(0.108)\end{array}$ & $\begin{array}{c}0.172 \\
(0.150)\end{array}$ & $\begin{array}{c}0.509 * * * \\
(0.197)\end{array}$ & $\begin{array}{l}0.270^{*} \\
(0.145)\end{array}$ & $\begin{array}{c}0.207 \\
(0.126)\end{array}$ & $\begin{array}{l}0.290^{*} \\
(0.176)\end{array}$ & $\begin{array}{c}0.326^{* *} \\
(0.137)\end{array}$ \\
\hline Log(Price Perennials) (t-2) & $\begin{array}{c}0.024 \\
(0.021)\end{array}$ & $\begin{array}{c}0.264 \\
(0.168)\end{array}$ & $\begin{array}{l}-0.143 \\
(0.110)\end{array}$ & $\begin{array}{c}0.011 \\
(0.144)\end{array}$ & $\begin{array}{l}0.327^{*} \\
(0.180)\end{array}$ & $\begin{array}{l}-0.173 \\
(0.145)\end{array}$ & $\begin{array}{c}0.015 \\
(0.099)\end{array}$ & $\begin{array}{c}0.258 \\
(0.163)\end{array}$ & $\begin{array}{l}-0.086 \\
(0.134)\end{array}$ \\
\hline Log(Price Perennials) (t-3) & $\begin{array}{c}-0.010 \\
(0.019)\end{array}$ & $\begin{array}{c}0.039 \\
(0.170)\end{array}$ & $\begin{array}{c}0.072 \\
(0.105)\end{array}$ & $\begin{array}{c}0.030 \\
(0.142)\end{array}$ & $\begin{array}{c}0.052 \\
(0.182)\end{array}$ & $\begin{array}{l}0.240^{*} \\
(0.137)\end{array}$ & $\begin{array}{c}-0.078 \\
(0.111)\end{array}$ & $\begin{array}{c}-0.171 \\
(0.165)\end{array}$ & $\begin{array}{l}0.245^{*} \\
(0.127)\end{array}$ \\
\hline Log(Price Perennials) $(\mathrm{t}-4)$ & $\begin{array}{c}0.017 \\
(0.016) \\
\end{array}$ & $\begin{array}{l}0.326^{*} \\
(0.176)\end{array}$ & $\begin{array}{c}0.457 * * * \\
(0.105)\end{array}$ & $\begin{array}{l}0.237 * \\
(0.141)\end{array}$ & $\begin{array}{l}0.314 * \\
(0.187)\end{array}$ & $\begin{array}{c}0.557 * * * \\
(0.138)\end{array}$ & $\begin{array}{l}0.212 * \\
(0.109)\end{array}$ & $\begin{array}{c}0.267 \\
(0.171) \\
\end{array}$ & $\begin{array}{c}0.647 * * * \\
(0.131) \\
\end{array}$ \\
\hline Log(Price Grains) (t-1) & $\begin{array}{c}-0.240 * * \\
(0.115)\end{array}$ & $\begin{array}{c}4.353 * * * \\
(1.030)\end{array}$ & $\begin{array}{c}-1.705 * * * \\
(0.535)\end{array}$ & $\begin{array}{c}-1.676^{* *} \\
(0.825)\end{array}$ & $\begin{array}{c}4.745^{* * * *} \\
(1.110)\end{array}$ & $\begin{array}{c}-3.499 * * * \\
(0.873)\end{array}$ & $\begin{array}{c}-1.357 * * \\
(0.598)\end{array}$ & $\begin{array}{c}4.971 * * * \\
(0.998)\end{array}$ & $\begin{array}{c}-2.803 * * * \\
(0.828)\end{array}$ \\
\hline Log(Price Grains) (t-2) & $\begin{array}{c}0.224 * * \\
(0.100)\end{array}$ & $\begin{array}{c}-4.825 * * * \\
(0.983)\end{array}$ & $\begin{array}{c}-0.225 \\
(0.511)\end{array}$ & $\begin{array}{c}0.787 \\
(0.744)\end{array}$ & $\begin{array}{c}-4.870 * * * \\
(1.059)\end{array}$ & $\begin{array}{c}0.286 \\
(0.779)\end{array}$ & $\begin{array}{c}0.401 \\
(0.512)\end{array}$ & $\begin{array}{c}-5.905 * * * \\
(0.961)\end{array}$ & $\begin{array}{c}0.251 \\
(0.748)\end{array}$ \\
\hline Log(Price Grains) (t-3) & $\begin{array}{c}0.045 \\
(0.088)\end{array}$ & $\begin{array}{c}0.961 \\
(1.012)\end{array}$ & $\begin{array}{c}2.193 * * * \\
(0.563)\end{array}$ & $\begin{array}{c}-0.148 \\
(0.716)\end{array}$ & $\begin{array}{c}1.155 \\
(1.093)\end{array}$ & $\begin{array}{c}3.287 * * * \\
(0.835)\end{array}$ & $\begin{array}{c}0.015 \\
(0.548)\end{array}$ & $\begin{array}{c}1.418 \\
(0.953)\end{array}$ & $\begin{array}{c}3.462 * * * \\
(0.802)\end{array}$ \\
\hline
\end{tabular}




\begin{tabular}{|c|c|c|c|c|c|c|c|c|c|}
\hline Log(Price Grains) (t-4) & $\begin{array}{l}-0.017 \\
(0.085) \\
\end{array}$ & $\begin{array}{c}2.261 * * \\
(0.995)\end{array}$ & $\begin{array}{c}-3.411 * * * \\
(0.571) \\
\end{array}$ & $\begin{array}{l}-0.769 \\
(0.687) \\
\end{array}$ & $\begin{array}{c}2.619 * * \\
(1.073)\end{array}$ & $\begin{array}{c}-4.902 * * * \\
(0.816)\end{array}$ & $\begin{array}{l}-0.550 \\
(0.538) \\
\end{array}$ & $\begin{array}{c}0.726 \\
(0.991) \\
\end{array}$ & $\begin{array}{c}-4.987 * * * \\
(0.781) \\
\end{array}$ \\
\hline $\log ($ Price Oil) $(\mathrm{t}-1)$ & $\begin{array}{c}0.015 \\
(0.057)\end{array}$ & $\begin{array}{c}0.402 \\
(0.639)\end{array}$ & $\begin{array}{c}0.299 \\
(0.264)\end{array}$ & $\begin{array}{c}-1.605^{* * *} \\
(0.441)\end{array}$ & $\begin{array}{c}0.317 \\
(0.698)\end{array}$ & $\begin{array}{c}0.779 \\
(0.495)\end{array}$ & $\begin{array}{c}-1.044 * * * \\
(0.354)\end{array}$ & $\begin{array}{l}1.255^{* *} \\
(0.619)\end{array}$ & $\begin{array}{l}0.771^{*} \\
(0.465)\end{array}$ \\
\hline $\log ($ Price Oil) $(\mathrm{t}-2)$ & $\begin{array}{l}-0.048 \\
(0.049)\end{array}$ & $\begin{array}{l}-0.116 \\
(0.501)\end{array}$ & $\begin{array}{c}-0.690 * * * \\
(0.199)\end{array}$ & $\begin{array}{c}-0.882 * * \\
(0.421)\end{array}$ & $\begin{array}{l}-0.083 \\
(0.545)\end{array}$ & $\begin{array}{c}-1.874 * * * \\
(0.395)\end{array}$ & $\begin{array}{l}-0.528^{*} \\
(0.288)\end{array}$ & $\begin{array}{c}0.037 \\
(0.476)\end{array}$ & $\begin{array}{c}-1.746 * * * \\
(0.381)\end{array}$ \\
\hline $\log ($ Price Oil) (t-3) & $\begin{array}{c}0.073 \\
(0.052)\end{array}$ & $\begin{array}{c}0.792 \\
(0.504)\end{array}$ & $\begin{array}{c}0.501 * * \\
(0.209)\end{array}$ & $\begin{array}{c}0.287 \\
(0.421)\end{array}$ & $\begin{array}{l}1.057 * \\
(0.550)\end{array}$ & $\begin{array}{c}0.643 \\
(0.399)\end{array}$ & $\begin{array}{l}0.433^{*} \\
(0.263)\end{array}$ & $\begin{array}{l}-0.128 \\
(0.496)\end{array}$ & $\begin{array}{l}0.671 * \\
(0.398)\end{array}$ \\
\hline $\log ($ Price Oil) $(\mathrm{t}-4)$ & $\begin{array}{l}-0.046 \\
(0.042) \\
\end{array}$ & $\begin{array}{l}-0.937 \\
(0.593) \\
\end{array}$ & $\begin{array}{c}0.346 \\
(0.238) \\
\end{array}$ & $\begin{array}{r}-0.312 \\
(0.363) \\
\end{array}$ & $\begin{array}{l}-1.024 \\
(0.661) \\
\end{array}$ & $\begin{array}{l}-0.030 \\
(0.419) \\
\end{array}$ & $\begin{array}{l}-0.226 \\
(0.302) \\
\end{array}$ & $\begin{array}{c}0.140 \\
(0.546) \\
\end{array}$ & $\begin{array}{l}-0.090 \\
(0.407) \\
\end{array}$ \\
\hline Log(Wage) (t-1) & $\begin{array}{l}0.689 * * \\
(0.327)\end{array}$ & $\begin{array}{c}-5.003 * * * \\
(1.575)\end{array}$ & $\begin{array}{c}1.245 \\
(0.980)\end{array}$ & $\begin{array}{c}3.349 * * * \\
(0.936)\end{array}$ & $\begin{array}{c}-5.330 * * * \\
(1.711)\end{array}$ & $\begin{array}{c}1.890 \\
(1.298)\end{array}$ & $\begin{array}{c}0.878 \\
(0.744)\end{array}$ & $\begin{array}{c}-3.639 * * \\
(1.601)\end{array}$ & $\begin{array}{l}2.400 * \\
(1.234)\end{array}$ \\
\hline Log(Wage) $(\mathrm{t}-2)$ & $\begin{array}{l}-0.334 \\
(0.242)\end{array}$ & $\begin{array}{l}-2.234 \\
(1.660)\end{array}$ & $\begin{array}{c}1.156 \\
(1.126)\end{array}$ & $\begin{array}{l}-1.857^{*} \\
(1.100)\end{array}$ & $\begin{array}{l}-2.520 \\
(1.809)\end{array}$ & $\begin{array}{c}0.884 \\
(1.515)\end{array}$ & $\begin{array}{l}-0.543 \\
(1.139)\end{array}$ & $\begin{array}{l}-2.148 \\
(1.633)\end{array}$ & $\begin{array}{l}-0.348 \\
(1.342)\end{array}$ \\
\hline Log(Wage) (t-3) & $\begin{array}{l}-0.146 \\
(0.282)\end{array}$ & $\begin{array}{c}4.709 * * * \\
(1.723)\end{array}$ & $\begin{array}{l}-0.308 \\
(1.263)\end{array}$ & $\begin{array}{l}-1.858 \\
(1.447)\end{array}$ & $\begin{array}{c}5.329 * * * \\
(1.885)\end{array}$ & $\begin{array}{c}0.469 \\
(1.659)\end{array}$ & $\begin{array}{l}-0.056 \\
(0.794)\end{array}$ & $\begin{array}{c}4.634 * * * \\
(1.582)\end{array}$ & $\begin{array}{c}1.686 \\
(1.320)\end{array}$ \\
\hline Log(Wage) (t-4) & $\begin{array}{c}0.183 \\
(0.222) \\
\end{array}$ & $\begin{array}{c}-3.019 * * \\
(1.331)\end{array}$ & $\begin{array}{l}-1.118 \\
(0.896)\end{array}$ & $\begin{array}{c}0.507 \\
(1.285)\end{array}$ & $\begin{array}{c}-3.735 * * \\
(1.454)\end{array}$ & $\begin{array}{l}-1.489 \\
(1.163)\end{array}$ & $\begin{array}{l}-0.578 \\
(0.719) \\
\end{array}$ & $\begin{array}{c}-2.724 * * \\
(1.235)\end{array}$ & $\begin{array}{l}-1.222 \\
(0.994)\end{array}$ \\
\hline Unemployment (t-1) & $\begin{array}{l}-0.000 \\
(0.014)\end{array}$ & $\begin{array}{c}-0.287 * * * \\
(0.095)\end{array}$ & $\begin{array}{c}-0.175^{* * * *} \\
(0.055)\end{array}$ & $\begin{array}{c}0.041 \\
(0.099)\end{array}$ & $\begin{array}{c}-0.309 * * * \\
(0.101)\end{array}$ & $\begin{array}{c}-0.264 * * * \\
(0.074)\end{array}$ & $\begin{array}{c}0.052 \\
(0.080)\end{array}$ & $\begin{array}{c}-0.257 * * * \\
(0.093)\end{array}$ & $\begin{array}{c}-0.299 * * * \\
(0.071)\end{array}$ \\
\hline Unemployment (t-2) & $\begin{array}{l}-0.007 \\
(0.015)\end{array}$ & $\begin{array}{l}0.195^{*} \\
(0.102)\end{array}$ & $\begin{array}{c}0.080 \\
(0.058)\end{array}$ & $\begin{array}{c}0.039 \\
(0.109)\end{array}$ & $\begin{array}{l}0.211^{*} \\
(0.109)\end{array}$ & $\begin{array}{c}0.112 \\
(0.075)\end{array}$ & $\begin{array}{c}0.116 \\
(0.091)\end{array}$ & $\begin{array}{c}0.138 \\
(0.098)\end{array}$ & $\begin{array}{c}0.156 * * \\
(0.072)\end{array}$ \\
\hline Unemployment (t-3) & $\begin{array}{l}-0.007 \\
(0.012)\end{array}$ & $\begin{array}{c}0.015 \\
(0.091)\end{array}$ & $\begin{array}{c}0.165 * * * \\
(0.054)\end{array}$ & $\begin{array}{c}-0.203 * * \\
(0.088)\end{array}$ & $\begin{array}{c}0.007 \\
(0.097)\end{array}$ & $\begin{array}{c}0.236 * * * \\
(0.069)\end{array}$ & $\begin{array}{c}-0.225 * * * \\
(0.079)\end{array}$ & $\begin{array}{c}0.042 \\
(0.089)\end{array}$ & $\begin{array}{c}0.225 * * * \\
(0.065)\end{array}$ \\
\hline Unemployment (t-4) & $\begin{array}{c}0.010 \\
(0.007)\end{array}$ & $\begin{array}{l}-0.029 \\
(0.074)\end{array}$ & $\begin{array}{c}0.007 \\
(0.045) \\
\end{array}$ & $\begin{array}{c}0.033 \\
(0.067)\end{array}$ & $\begin{array}{l}-0.032 \\
(0.079)\end{array}$ & $\begin{array}{l}-0.035 \\
(0.058)\end{array}$ & $\begin{array}{c}0.050 \\
(0.052) \\
\end{array}$ & $\begin{array}{l}-0.011 \\
(0.072)\end{array}$ & $\begin{array}{l}-0.068 \\
(0.055)\end{array}$ \\
\hline Constant & $\begin{array}{c}-2.807 * * \\
(1.396)\end{array}$ & $\begin{array}{c}59.280 * * * \\
(10.406)\end{array}$ & $\begin{array}{c}-10.871 * * \\
(5.470)\end{array}$ & $\begin{array}{l}-15.355 \\
(10.189)\end{array}$ & $\begin{array}{c}54.848 * * * \\
(14.153)\end{array}$ & $\begin{array}{c}-41.449 * * * \\
(10.552)\end{array}$ & $\begin{array}{l}-6.287 \\
(7.522)\end{array}$ & $\begin{array}{c}35.464 * * * \\
(12.908)\end{array}$ & $\begin{array}{c}-43.534 * * * \\
(10.021)\end{array}$ \\
\hline Observations & 44,266 & 44,266 & 44,266 & 44,266 & 44,266 & 44,266 & 41,517 & 41,517 & 41,517 \\
\hline $\begin{array}{l}\text { Rayon FE } \\
\text { Year FE }\end{array}$ & $\begin{array}{l}\text { YES } \\
\text { YES }\end{array}$ & $\begin{array}{l}\text { YES } \\
\text { YES }\end{array}$ & $\begin{array}{l}\text { YES } \\
\text { YES }\end{array}$ & $\begin{array}{l}\text { YES } \\
\text { YES }\end{array}$ & $\begin{array}{l}\text { YES } \\
\text { YES }\end{array}$ & $\begin{array}{l}\text { YES } \\
\text { YES }\end{array}$ & $\begin{array}{l}\text { YES } \\
\text { YES }\end{array}$ & $\begin{array}{l}\text { YES } \\
\text { YES }\end{array}$ & $\begin{array}{l}\text { YES } \\
\text { YES }\end{array}$ \\
\hline
\end{tabular}


Table A.3. Response of crop mix across the farm sizes

\begin{tabular}{|c|c|c|c|c|c|c|}
\hline & All farms & $0.1-200$ ha & 200.1-1000 & 1000.1-2000 & 2000.1-5000 & Above 5000.1 ha \\
\hline Observations & 44,266 & 2,749 & 12,032 & 12,417 & 13,745 & 3,323 \\
\hline \multicolumn{7}{|c|}{ Panel A. Share of perennial crops } \\
\hline Rented share (t-1) & $\begin{array}{l}-0.013 \\
(0.008)\end{array}$ & $\begin{array}{l}-0.365^{*} \\
(0.194)\end{array}$ & $\begin{array}{l}-0.009 \\
(0.023)\end{array}$ & $\begin{array}{c}0.007 \\
(0.007)\end{array}$ & $\begin{array}{l}-0.006 \\
(0.010)\end{array}$ & $\begin{array}{c}-0.004^{* * *} \\
(0.000)\end{array}$ \\
\hline \multirow[t]{2}{*}{ Rented share (t-2) } & -0.010 & $0.299^{* *}$ & $-0.032^{*}$ & $-0.023^{* *}$ & 0.002 & 0.000 \\
\hline & $(0.008)$ & $(0.139)$ & $(0.019)$ & $(0.009)$ & $(0.008)$ & $(0.000)$ \\
\hline \multirow[t]{2}{*}{ Rented share (t-3) } & 0.001 & 0.012 & 0.008 & 0.001 & -0.000 & $0.001^{\text {**** }}$ \\
\hline & $(0.006)$ & $(0.107)$ & $(0.018)$ & $(0.008)$ & $(0.004)$ & $(0.000)$ \\
\hline \multirow[t]{2}{*}{ Rented share (t-4) } & $-0.015^{* * *}$ & -0.040 & -0.021 & $-0.013^{* *}$ & $-0.004^{*}$ & $0.004^{* * *}$ \\
\hline & $(0.004)$ & $(0.118)$ & $(0.015)$ & $(0.005)$ & $(0.002)$ & $(0.000)$ \\
\hline $\begin{array}{l}\text { Sum of short-run Perennial } \\
\text { crops response }\end{array}$ & $\begin{array}{c}-0.038^{* * *} \\
(0.004)\end{array}$ & $\begin{array}{l}-0.093 \\
(0.100)\end{array}$ & $\begin{array}{c}-0.054^{* * *} \\
(0.012)\end{array}$ & $\begin{array}{c}-0.028^{* * * *} \\
(0.007)\end{array}$ & $\begin{array}{c}-0.009^{* * * *} \\
(0.003)\end{array}$ & $\begin{array}{c}0.001 \\
(0.002)\end{array}$ \\
\hline \multicolumn{7}{|c|}{ Panel B. Share of grain crops } \\
\hline \multirow[t]{2}{*}{ Rented share (t-1) } & $0.046^{* * * *}$ & $0.160^{*}$ & $0.062^{* * * *}$ & $0.034^{* *}$ & $0.026^{* *}$ & -0.007 \\
\hline & $(0.011)$ & $(0.087)$ & $(0.022)$ & $(0.015)$ & $(0.011)$ & $(0.028)$ \\
\hline \multirow[t]{2}{*}{ Rented share (t-2) } & 0.001 & 0.010 & -0.008 & 0.010 & -0.003 & $0.089^{* * *}$ \\
\hline & $(0.012)$ & $(0.111)$ & $(0.023)$ & $(0.017)$ & $(0.011)$ & $(0.034)$ \\
\hline \multirow[t]{2}{*}{ Rented share (t-3) } & -0.005 & -0.073 & -0.025 & 0.000 & $0.025^{* * *}$ & -0.000 \\
\hline & $(0.011)$ & $(0.116)$ & $(0.023)$ & $(0.015)$ & $(0.010)$ & $(0.024)$ \\
\hline \multirow[t]{2}{*}{ Rented share (t-4) } & $0.029^{* * * *}$ & $0.148^{*}$ & $0.059^{* * *}$ & $0.018^{*}$ & 0.005 & -0.000 \\
\hline & $(0.008)$ & $(0.087)$ & $(0.016)$ & $(0.010)$ & $(0.008)$ & $(0.017)$ \\
\hline $\begin{array}{l}\text { Sum of short-run Grain } \\
\text { crops response }\end{array}$ & $\begin{array}{l}0.070^{* * *} \\
(0.005)\end{array}$ & $\begin{array}{l}0.245^{* * *} \\
(0.069)\end{array}$ & $\begin{array}{r}0.088^{* * *} \\
(0.012)\end{array}$ & $\begin{array}{l}0.062^{* * * *} \\
(0.009)\end{array}$ & $\begin{array}{l}0.053^{* * *} \\
(0.006)\end{array}$ & $\begin{array}{l}0.081^{* * *} \\
(0.013)\end{array}$ \\
\hline \multicolumn{7}{|c|}{ Panel C. Share of oil crops } \\
\hline Rented share (t-1) & $\begin{array}{l}0.022^{* * *} \\
(0.008)\end{array}$ & $\begin{array}{l}0.085^{* *} \\
(0.035)\end{array}$ & $\begin{array}{c}0.030^{* * *} \\
(0.004)\end{array}$ & $\begin{array}{c}0.017 \\
(0.011)\end{array}$ & $\begin{array}{l}0.017^{* * *} \\
(0.002)\end{array}$ & $\begin{array}{c}-0.022^{* * * *} \\
(0.002)\end{array}$ \\
\hline \multirow[t]{2}{*}{ Rented share (t-2) } & 0.008 & $0.144^{* * * *}$ & 0.000 & 0.011 & $0.013^{* * * *}$ & $0.043^{* * * *}$ \\
\hline & $(0.008)$ & $(0.038)$ & $(0.005)$ & $(0.013)$ & $(0.002)$ & $(0.002)$ \\
\hline \multirow[t]{2}{*}{ Rented share (t-3) } & 0.003 & $0.173^{* * *}$ & $-0.019^{* * *}$ & 0.008 & 0.001 & $0.018^{* * *}$ \\
\hline & $(0.007)$ & $(0.039)$ & $(0.004)$ & $(0.012)$ & $(0.002)$ & $(0.002)$ \\
\hline \multirow[t]{2}{*}{ Rented share (t-4) } & $0.009^{*}$ & $-0.205^{* * *}$ & $0.047^{* * * *}$ & $0.017^{*}$ & $0.006^{* * *}$ & $0.017^{* * *}$ \\
\hline & $(0.005)$ & $(0.030)$ & $(0.004)$ & $(0.009)$ & $(0.001)$ & $(0.002)$ \\
\hline
\end{tabular}




\begin{tabular}{|c|c|c|c|c|c|c|}
\hline $\begin{array}{l}\text { Sum of short-run Oil crops } \\
\text { response }\end{array}$ & $\begin{array}{l}0.043^{* * *} \\
(0.004) \\
\end{array}$ & $\begin{array}{c}0.197 \\
(0.140) \\
\end{array}$ & $\begin{array}{l}0.058^{* * *} \\
(0.017) \\
\end{array}$ & $\begin{array}{l}0.053^{* * *} \\
(0.007) \\
\end{array}$ & $\begin{array}{l}0.037^{* * *} \\
(0.007) \\
\end{array}$ & $\begin{array}{c}0.057^{* * *} \\
(0.009) \\
\end{array}$ \\
\hline \multicolumn{7}{|c|}{ Panel D. Difference in response across crops (in the short-run) } \\
\hline Perennial vs. annual & $\begin{array}{l}-0.108^{* * *} \\
(0.007)\end{array}$ & $\begin{array}{l}-0.338^{* * * *} \\
(0.118)\end{array}$ & $\begin{array}{l}-0.141^{* * *} \\
(0.018)\end{array}$ & $\begin{array}{l}-0.091^{* * *} \\
(0.012)\end{array}$ & $\begin{array}{c}-0.062^{* * *} \\
(0.007)\end{array}$ & $\begin{array}{l}-0.081^{* * *} \\
(0.013)\end{array}$ \\
\hline Perennial vs. oil & $\begin{array}{c}-0.081^{* * * *} \\
(0.006)\end{array}$ & $\begin{array}{l}-0.290 \\
(0.181)\end{array}$ & $\begin{array}{l}-0.111^{* * *} \\
(0.021)\end{array}$ & $\begin{array}{l}-0.081^{* * *} \\
(0.010)\end{array}$ & $\begin{array}{c}-0.046^{* * *} \\
(0.007)\end{array}$ & $\begin{array}{c}-0.056^{* * *} \\
(0.009)\end{array}$ \\
\hline Annual vs. oil & $\begin{array}{l}0.027^{* * * *} \\
(0.005)\end{array}$ & $\begin{array}{c}0.048 \\
(0.160) \\
\end{array}$ & $\begin{array}{r}0.030 \\
(0.022) \\
\end{array}$ & $\begin{array}{c}0.010 \\
(0.009) \\
\end{array}$ & $\begin{array}{c}0.016 \\
(0.010) \\
\end{array}$ & $\begin{array}{c}0.025 \\
(0.018) \\
\end{array}$ \\
\hline
\end{tabular}

Note: Based on system of SUR estimated with tobit; Marginal effects are presented; Robust standard errors in parentheses; $* * * \mathrm{p}<0.01, * * \mathrm{p}<0.05$, $* \mathrm{p}<0.1$ 